\title{
Brazilian Plants: An Unexplored Source of Endophytes as Producers of Active Metabolites
}

Authors

Daiani Cristina Savi, Rodrigo Aluizio, Chirlei Glienke

\author{
Affiliation \\ Federal University of Paraná, Department of Genetics, \\ Curitiba, Brazil
}

Key words

Brazilian biodiversity, medicinal plants, endophytes, secondary metabolites

received December 11, 2018

revised January 22, 2019

accepted January 29, 2019

Bibliography

DOI https://doi.org/10.1055/a-0847-1532

Published online February 11, 2019 | Planta Med 2019; 85:

619-636 @ Georg Thieme Verlag KG Stuttgart · New York | ISSN 0032-0943

\author{
Correspondence \\ Daiani Cristina Savi PhD. \\ Federal University of Paraná, Department of Genetics \\ Av. Cel. Francisco H. dos Santos, 100, 81531-990, \\ Curitiba, Brazil \\ Phone: + 55413361656 , Fax: + 554133611562 \\ daianicsavi@gmail.com \\ Supporting information available online at \\ http://www.thieme-connect.de/products
}

\begin{abstract}
Brazil has an extraordinary biodiversity, and for many years, has been classified as the first of 17 countries with a mega diversity, with $22 \%$ of the total plants in the world (more than 55000 species). Considering that some endophytes are hostspecific, the incomparable plant diversity found in Brazil encompasses an immeasurable variety of habitats and may represent a repository of unexplored species. As a result of the endophyte-host interaction, plant-associated microorganisms have an enormous biosynthetic potential to produce compounds with novelties in structure and bioactivity. Numerous studies have been published over the years describing the endophytic species isolated in Brazil. Identification of these species is generally performed via DNA sequencing. However, many of the genera to which the described taxa belong were reviewed phylogenetically and many species were reclassified. Thus, there is a gap in the real biodiversity of endophytes isolated in Brazil in the last decade. In this scenario, the present study reviewed the biodiversity of endophytes isolated from plants found in different Brazilian biomes from 2012 to 2017, including the following topics: (i) species diversity, (ii) species identification challenges, (iii) biotechnological aspects, and (iv) identified metabolites. Endophytes of 54 species of plants were studied from 2012 to 2017, resulting in the identification of 300 genera, with Diaporthe and Bacillus being the most frequent fungal and bacterial genera, respectively.
\end{abstract}

\section{Introduction}

The discovery of new compounds for pharmaceutical and agronomic purposes is now more necessary than ever [1]. In drug discovery programs, nature remains an unlimited source of complex molecules. Plants have served as a repository of medicinal bioactive compounds against numerous diseases for centuries, however, the isolation and purification of plant compounds in an adequate yield remains a major concern [2]. In addition to the low yield, the exploitation of plants for extraction of metabolites is also associated with environmental impacts, and new strategies, such as the use of endophytic microorganisms instead of the plants themselves, have offered compounds with high therapeutic potential [3].

Microorganisms are well known for their ability to produce secondary metabolites that are applied in medicine and agriculture, and endophytes have gained remarkable attention in view of their diversity and biotechnological potential [4]. The long relationship of endophytes with medicinal plants may influence the natural bioactivity of endophytes by acquiring genetic information from the plant to produce host-like metabolites [4]. The hypothesis of genetic exchange involving the endophyte and its host is supported by the presence of host-like genes in the biosynthetic pathways of endophytes, resulting in a huge repertoire of enzymes and the production of complex molecules. A great example of the plant-endophyte relationship is the production of paclitaxel by the endophytic fungus Taxomyces andreanae, a compound produced primarily by the host, Taxus sp. [5]. Despite the large number of studies reporting synergism in the metabolic pathways, our knowledge of the exact mechanisms involving the host-endophyte relationship remains limited [3]. 
It is estimated that more than one million endophytic species occur in nature, and less than $10 \%$ of these species are cataloged [3]. The challenge in exploring endophytes for drug discovery lies in how to access the potential of chemical diversity, since the population of endophytes is highly variable and depends on several components, such as host species and environmental conditions [6]. In this scenario, tropical forests, such as the Brazilian flora that holds about 55000 species of terrestrial plants [7], may represent an interesting repository of new endophytic species that can be used as a repertoire of new molecules.

An important step in the bioprospecting of microorganisms involves accurate identification of the species to ensure correct reporting of the biochemical potential of each species. The precise identification of microorganisms involves morphological, biochemical, and genetic analyses. However, due to an inadequate interpretation of DNA sequences (using only blast analysis in public databases), several studies have identified endophytes incorrectly or incompletely (only at the genus or family level).

Based on these data, this study reviewed the biodiversity of endophytes of plants found in different Brazilian biomes from 2012 to 2017 , including species diversity, species identification challenges, and biotechnological aspects.

\section{Definition of endophytes and strategies for plant colonization}

De Bary [8] suggested that endophytes are microorganisms that dwell within plant tissues. Based on the microscopic analysis, Petrini [9] suggested that endophytes are microorganisms that interact with the host plant and as a result of this interaction, no symptoms of disease are observed. The problem with the definitions of endophytes proposed by De Bary [8] and Petrini [9] is related to some latent pathogens that live part of their life inside plants tissues without causing any negative damage. In this context, Hardoim et al. [10] suggested that the term endophyte refers only to habitat and should not be associated with a function, for example, phytopathogenic or non-phytopathogenic, and all microorganisms that throughout all or part of their life colonize the internal tissues of plants are considered endophytes.

The coexistence of plants and endophytes remains unclear [11], and the main question is: Why do plants not defend themselves against internal colonizers? So far, it seems that the momentary symbiotic relationship between the plant and the endophyte is established [12]. The endophytes provide nutrients for the plant, can also facilitate the acquisition of essential nutrients from the environment, such as nitrogen, phosphorous, and iron [13], and produce secondary metabolites that can inhibit an infection by phytopathogens [14]. The main factors that can regulate endophytic colonization within a plant include plant genotype, growth stage, tissue physiology, colonized plant tissue, and environmental conditions. The genetic factors of the host can critically influence the structure and function of the microbiomes associated with the plants. Thus, endophytes seem to have successfully adapted to overcome a host-specific immune system and, thus, to form populations in the internal tissues [4]. To overcome plant defense mechanisms, endophytes produce secondary metabolites or enzymes, such as cellulases, lactases, and proteases, which can damage the plant cell wall and facilitate penetration into the host [14]. Another system also used by endophytes in plant colonization involves opportunistic penetration through wounds or roots [13].

Once within the plant tissues, the endophyte colonizes the tissues without causing symptoms, but at any time, due to environmental changes such as plant development, availability of nutrients, or other factors, that relationship can be broken and the symptoms of the disease can be observed [15].

\section{Plants explored as a source of endophytes in Brazil}

The Brazilian diversity is divided into six biomes: the Amazonian rainforest, the Caatinga, the Cerrado (Savannah), the Atlantic Forest, the Pampa, and the Pantanal (Swampland) [16]. For several years, the International Conservation has placed Brazil at the top of the 17 megadiverse countries of the world, with the largest number of plant species, 55000 , representing $22 \%$ of the world total (http://www.unesco.org/new/en/brasilia/natural-sciences/ environment/biodiversity/). Considering that some endophytes are host-specific, the diversity of plants found in Brazil comprises an extraordinary diversity of habitats, life forms, and biological associations confined to particular environments at different geographic scales. Although plant diversity is well documented, the number and richness of microorganisms in most countries remain unlisted, and Brazil is no exception. In view of species richness, two biomes are recognized as global biodiversity hot spots, the Brazilian Cerrado and the Atlantic Forest [16], and can represent an inexhaustible source of microorganisms.

A search using the words "endophytes" and "Brazil" in the PubMed database resulted in 67 papers that performed isolation and bioprospecting of endophytes from Brazilian biomes during 2012-2017. From the analyzed articles, the data collected were the name of the plant from which the endophytes were isolated, the endophytes isolated from each plant, the methods used to identify the endophytes, the biotechnological potential of the endophytes, and the isolated secondary metabolites. Endophytes were grouped at kingdom and family levels based on Mycobank [MycoBank (http://www.mycobank.org/) classification and list of prokaryotic names with standing nomenclature (http://www. bacterio.net/)].

- Table 1 lists the scientific names of the 54 plant species of which the endophytes were isolated in Brazil from 2012 to 2017. The plants studied belong to 30 families and the frequency of each family is shown in - Fig. $\mathbf{1}$. The most representative plant families are Fabaceae, Myrtaceae, and Asteraceae, representing more than $25 \%$ of the studies ( $\boldsymbol{\vee}$ Fig. $\mathbf{1}$ ). The Fabaceae family includes several important agricultural and food plants, and Asteraceae members provide products such as cooking oils, sunflower seeds, and sweetening agents. The Myrtaceae family also provides many products, including timber, essential oils, and horticultural plants (http://tolweb.org). Interestingly, the most representative families have obvious significance in the agriculture and food industries; in contrast, fewer studies have been conducted on the biodiversity of endophytes of medicinal plants. Biomes and the 
- Table 1 Taxonomic classification of plants containing endophytes and the collection sites. The scientific names of the plants were searched in the NCBI Taxonomy database to note the family in which the plant is classified.

\begin{tabular}{|c|c|c|c|}
\hline Plant & Family & City and State & Reference \\
\hline Alibertia macrophylla & Rubiaceae & São Paulo, São Paulo & [71] \\
\hline Alternanthera brasiliana & Amaranthaceae & São Paulo, São Paulo & {$[72]$} \\
\hline Ananas comosus & Bromeliaceae & São Paulo, São Paulo & [73] \\
\hline Aspidosperma tomentosum & Apocynaceae & Rio de Janeiro, Rio de Janeiro & [74] \\
\hline Avicennia nitida & Verbenaceae & Cananéia, São Paulo & {$[75]$} \\
\hline Avicennia schaueriana & Verbenaceae & Bertioga, São Paulo & [39] \\
\hline Baccharis trimera & Asteraceae & Ouro Branco, Minas Gerais & [76] \\
\hline Bauhinia forficate & Fabaceae & Recife, Pernambuco & [77] \\
\hline Bauhinia guianensis & Fabaceae & Manus, Amazonas & {$[78]$} \\
\hline Borreria verticillata & Rubiaceae & Recife, Pernambuco & {$[56]$} \\
\hline Citrus sinensis & Rutaceae & Piracicaba, São Paulo & [79] \\
\hline Coffea Arabica & Rubiaceae & Viçosa, Minas Gerais & {$[80]$} \\
\hline Eichhornia azurea & Pontederiaceae & Porto Rico, Paraná & [81] \\
\hline Eichhornia crassipes & Pontederiaceae & Porto Rico, Paraná & {$[81]$} \\
\hline Eucalyptus benthamii & Myrtaceae & São Paulo, São Paulo & {$[82]$} \\
\hline Eucalyptus grandis & Myrtaceae & Belo Oriente, Minas Gerais & [83] \\
\hline Eucalyptus urophylla & Myrtaceae & Belo Oriente, Minas Gerais & [83] \\
\hline Eugenia bimarginata & Myrtaceae & Belo Orizonte, Minas Gerais & [29] \\
\hline Fragaria chiloensis & Rosaceae & Lavras, Minas Gerais & {$[84]$} \\
\hline Glycine max & Fabaceae & Viçosa, Minas Gerais & {$[85]$} \\
\hline Hadrolaelia jongheana & Orchidaceae & Serra do Brigadeiro, Minas Gerais & [71] \\
\hline Hoffmannseggella caulescens & Orchidaceae & Serra do Brigadeiro, Minas Gerais & [71] \\
\hline Hoffmannseggella cinnabarina & Orchidaceae & Serra do Brigadeiro, Minas Gerais & [71] \\
\hline Hyptis suaveolens & Lamiaceae & Miranda, Mato Grosso do Sul & {$[50]$} \\
\hline Laguncularia racemose & Combretaceae & Cananéia, São Paulo & {$[60]$} \\
\hline Lippia sidoides & Verbenaceae & São Cristóvão, Sergipe & {$[86]$} \\
\hline Luehea divaricate & Malvaceae & Maringá, Paraná & [87] \\
\hline Lychnophora ericoides & Asteraceae & Furnas, Minas Gerais & [35] \\
\hline Maytenus ilicifolia & Celastraceae & Curitiba, Parana & {$[20]$} \\
\hline Melia azedarach & Meliaceae & São Carlos, São Paulo & {$[66]$} \\
\hline Musa spp & Musacea & Manacapuru, Amazonas & [39] \\
\hline Myrcia guianensis & Myrtaceae & Santarém, Bahia & {$[88]$} \\
\hline Opuntia ficus-indica & Cactaceae & Itaıba, Pernambuco & [77] \\
\hline Oryza glumaepatula & Poaceae & Seropédica, Rio de Janeiro & {$[52]$} \\
\hline Paullinia cupana & Sapindaceae & Manus, Amazonas & [53] \\
\hline Phaseolus vulgaris & Fabaceae & Viçosa, Minas Gerais & [89] \\
\hline Piper hispidum & Piperaceae & Maringa, Paraná & {$[38]$} \\
\hline Rhizophora mangle & Rhizophoraceae & Cananéia, São Paulo & [75] \\
\hline Ricinus communis & Euphorbiaceae & Curitiba, Paraná & {$[90]$} \\
\hline Saccharum officinarum & Poaceae & Seropédica, Rio de Janeiro & [91] \\
\hline Schinus terebinthifolius & Anacardiaceae & Curitiba, Paraná & {$[20]$} \\
\hline Senna spectabilis & Fabaceae & Araraquara, São Paulo & [2] \\
\hline Smallanthus sonchifolius & Asteraceae & Ribeirão Preto, Sâo Paulo & [92] \\
\hline Solanum cernuum & Solanaceae & Belo Horizonte, Minas Gerais & {$[32]$} \\
\hline Spondias mombin & Anacardiaceae & Redenção, Pará & {$[74]$} \\
\hline
\end{tabular}


- Table 1 Continued

\begin{tabular}{|l|l|l|l|}
\hline Plant & Family & City and State & Reference \\
\hline Strychnos toxifera & Loganiaceae & Manaus, Amazonas & {$[61]$} \\
\hline Theobroma cacao & Malvaceae & Braslia, Distrito Federal & {$[40]$} \\
\hline Trichilia elegans & Meliaceae & Maringá, Paraná & {$[93]$} \\
\hline Vellozia gigantean & Velloziaceae & Tocantins & {$[94]$} \\
\hline Vernonia polyanthes & Asteraceae & Ouro Preto, Minas Gerais & {$[68]$} \\
\hline Vigna unguiculata & Fabaceae & Juazeiro, Bahia & {$[95]$} \\
\hline Vitis labrusca & Vitaceae & Salesópolis, São Paulo & {$[96]$} \\
\hline Vochysia divergens & Vochysiaceae & Miranda, Mato Grosso do Sul & {$[27]$} \\
\hline Zea mays & Poaceae & Anchieta, Espirito Santos & {$[50]$} \\
\hline
\end{tabular}

approximate location where the collections were made were estimated using "Google Maps" (https://www.google.com.br/maps) and compared with the biome map proposed by Myers et al. [16] ( $\vee$ Fig. 2). The highest number of collections was carried out in the Atlantic Forest biome, mainly in the states of São Paulo, Minas Gerais, and Paraná, with the largest species cataloged in these states. In recent years, no studies on endophytic biodiversity have been conducted in Pampa ( $\bullet$ Fig. 2).

\section{Diversity of Endophytes in Brazil}

\section{Taxonomic classification}

Table 1S, Supporting Information, contains a taxonomic identification of the microorganisms isolated as endophytes from the plants listed in - Table $\mathbf{1}$. Of the 54 species of plants studied, 307 species (belonging to 300 genera) were reported (Table 1S, Supporting Information), 51 and $49 \%$ of the isolated genera belong, respectively, to the kingdoms bacteria and fungi ( $\bullet$ Fig. 3 ).

Among the bacteria kingdom, more than $50 \%$ of genera belong to the phylum Proteobacteria, followed by Actinobacteria and Firmicutes ( $\bullet$ Fig. 3). As reported previously [17], 99\% of fungal genera isolated as endophytes belong to the Ascomycota and Basidiomycota phylum, with the dominance of Ascomycota isolates ( 85\%) ( $\vee$ Fig. 3 ).

- Fig. 4 represents the number of occurrences of different endophytic genera in the studies in Brazil from 2012 to 2017. Diaporthe was the fungal genus reported in the largest number of studies, present as an endophyte in $48 \%$ of the analyzed articles $(\vee$ Fig. 4). Among the bacteria, Bacillus was the most frequent genus identified in $77 \%$ of the articles ( $\triangleright$ Fig. 4 ). These data agree with several studies on the biodiversity of endophytes $[18,19]$. Possibly the Diaporthe and Bacillus species have developed effective strategies to escape plant defenses, or even produce metabolites that may be useful for host development or defense against plant pathogens [20-22]. Despite the high diversity of endophytes of Brazilian plants (Table 1S, Supporting Information), of the 300 genera reported as endophytes, 101 bacteria and 83 fungal genera were reported as endophytes in only one publication ( $\triangleright$ Fig. 4 and Table S1, Supporting Information), suggesting that the endophytic community in Brazil remains little explored.

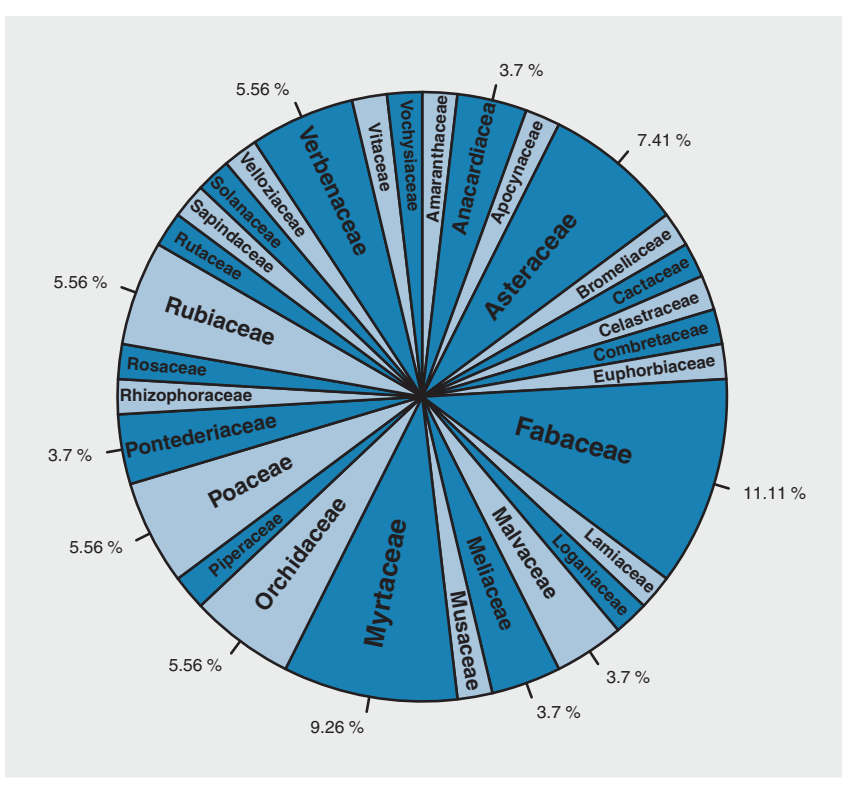

- Fig. 1 Families of plants from which endophytes have been isolated. The size of the wedges is proportional to the number of genera that correspond to each family.

\section{Problems in DNA sequence analysis}

The identification of endophytes at the species level is performed based on taxonomy, ecology, and applied reasons, such as the discovery of new products based on genomic analysis. Raja et al. [23] reported that $28 \%$ of the articles published in the Journal of Natural Products did not have any identification for fungal strains producing active molecules, and $31 \%$ of strain identification was based only on morphological aspects. Because correct species identification is a key step in ensuring reproducibility for biotechnology purposes and may reveal important information about its possible biochemical properties, a correct and robust method for species recognition should be applied in biodiversity studies and bioprospecting of endophytes.

For many years, microbiologists have used morphology as the sole criterion for species identification. However, morphological characteristics do not always present good performance in the 


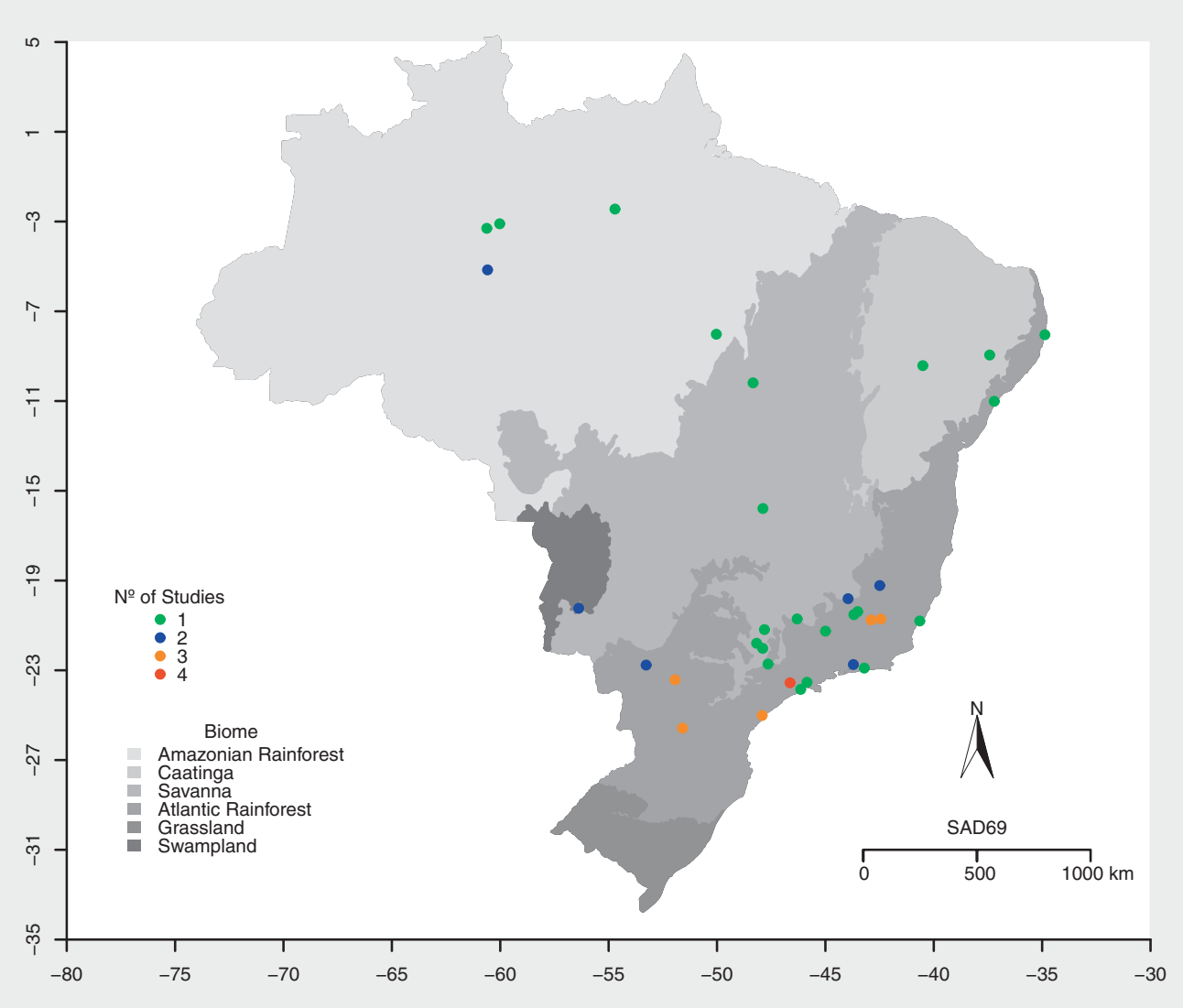

- Fig. 2 Collection sites of plants harboring endophytes in different Brazilian biomes. Site locations of collected plants were estimated with "Google Maps" (https://www.google.com.br/maps) based on the information provided in the literature. The circles and their colors indicate where and the number of studies performed.

identification of the species, and the absence of phenotypic information, such as the lack of sporulation in laboratory conditions, increase the difficulties of identification, even at the genus level [24]. Thus, molecular approaches become a reliable alternative for the identification of endophytes.

To date, the ITS and 16S rRNA regions remain the first choice for identification of fungi and bacteria, respectively. In the analyzed articles, 95.5\% used molecular markers to identify species and the majority, 93.5\%, used only one ribosomal marker (Table 1S, Supporting Information). However, to identify cryptic species in some genera, such as Diaporthe [25], Fusarium [26], Microbispora [27], and Streptomyces [28], ribosomal markers are not informative enough. In addition to this problem, most of the analyzed papers performed the identification of the strains based on similarity, comparing the DNA sequences with the GenBank database using the BLAST tool. However, it is already known that BLAST search-based identifications should be carried out with caution since in GenBank, there are misidentified sequences and entries with other annotation problems [23]. An interesting alternative that can minimize these problems is to use the "sequence from type" filter in the blast searches, or to conduct searches in the RefSeq Targeted Loci project (http://www.ncbi.nlm.nih.gov/ refseq/targetedloci/), which maintains curated sets of full-length sequences of type material for ribosomal RNAs [25]. Therefore, in order to obtain a correct identification of the species, this should be performed through a phylogenetic analysis using an evolutionary framework with homologous sequences of all type strain of each genus [23]. In contrast to similarity-based identification, phylogeny reconstructs the tree-like pattern that describes the evolutionary relationships between species with a predictive value [25].

In order to evaluate the accuracy of the species identification of endophytes isolated in Brazil, we have reanalyzed the sequences published in 18 articles describing strains with biotechnological potential ( $\triangleright$ Table 2 ). First, the sequences were compared to the sequences available in the GenBank database (http://www.ncbi.nlm.nih.gov/BLAST/) using the Blast tool, and selecting the option "blast only in type strains sequences". The value of $95 \%$ similarity was used as discriminatory for identification at the genus level. Sequences of all type strains of each genus of fungi and bacteria were obtained from MycoBank (http://www. mycobank.org/) and from the list of prokaryotic names with standing in nomenclature (http://www.bacterio.net/), respectively. The species identification of each strain was based on Bayesian phylogenic analysis according to Savi et al. [27]. 
We performed 27 new phylogenetic analyzes of 78 isolates belonging to 26 genera ( $\bullet$ Table 2 and Figs. 1S-27S, Supporting Information) in order to verify if the published identifications are correct or if there are misidentified species. Based on these analyses, we noticed that two isolates were erroneously identified at the genus level in the previous articles: Pereira et al. [29] identified the strain UFMGCB2032 (Genbank code KF681521), isolated from Eugenia bimarginata, as Mycosphaerella sp. based on phylogenetic analysis. The authors used only ITS sequences from a few type species of the Mycosphaerella genus and other GenBank sequences. However, Crous [30], using morphological and molecular approaches, demonstrated that Mycosphaerella is polyphyletic and represents a complex of genera and species, containing about 10000 species names, and has been split into more than 23 genera based on phylogenetic analysis and asexual morphs [30,31]. Based on these data and the previously listed article, we found that the isolate reported by Pereira shows high similarity to sequences of the genus Phaeophleospora, and in our new phylogenetic analysis (Fig.19S, Supporting Information), the strain UFMGCB2032 is clustered to Phaeophleospora gregaria, Phaeophleospora scytalidii, and Phaeophleospora eugeniicola, confirming the identification of this strain as Phaeophleospora sp. The second misidentification at the genus level was performed by Vieira et al. [32] for the isolate UFMGCB4428 (GeneBank code KJ404203) (Fig. 8S, Supporting Information). The authors identified strain UFMGCB4428 as Chaetomium sp. based on $90 \%$ similarity in BLAST analysis. However, despite the poor sequence quality (represented by several indeterminate bases, "N", present in the sequence), the first $190 \mathrm{bp}$ of the ITS sequence do not have similarity to the ITS sequences of the Chaetomium species, which may suggest a mixture of DNA sequences.

Isolate RLe10 (GenBank code KF057058) was identified as Kitasatospora cystarginea by Conti et al. [33]. However, several reports have shown that the partial sequences of 16S rRNA did not have enough information to differentiate Kitasotospora species from Streptomyces [28,34], as observed in our analysis (Fig. 26S, Supporting Information). A multilocus approach is required for the identification of species in these cryptic genera.

The remaining 75 isolates were correctly identified at the genus level, however, 17 isolates belonging to the genera Aspergillus, Phyllosticta, Colletotrichum, Lasiodiplodia, Streptomyces, and Bacillus were misidentified at the species level ( $\bullet$ Table 2) [33, 35-40].

The difference in the identification of two isolates belonging to species of Phyllosticta and Lasidioplodia genera ( $\triangleright$ Table 2) published by Orlandelli et al. [38] was due to the description of new species in the genera Phyllosticta and Lasiodiplodia after their publication. In these cases, the isolates clustered with more than one species (Figs. 21S and 13S, Supporting Information), making identification at the species level impossible. As an example, the species Phyllosticta paracapitalensis, recently described, is not differentiated from Phyllosticta capitalensis using only ITS sequences [41], requiring a multilocus sequence for species identification.

Silva et al. [36], Souza et al. [39], and Falcão et al. [40] erroneously identified several isolates at the species level in the genera Aspergillus and Bacillus. In our phylogenetic analyses, these isolates were not identified at the species level, but as belonging to Aspergillus section terrei and Bacillus section subtilis (Figs. 4S and

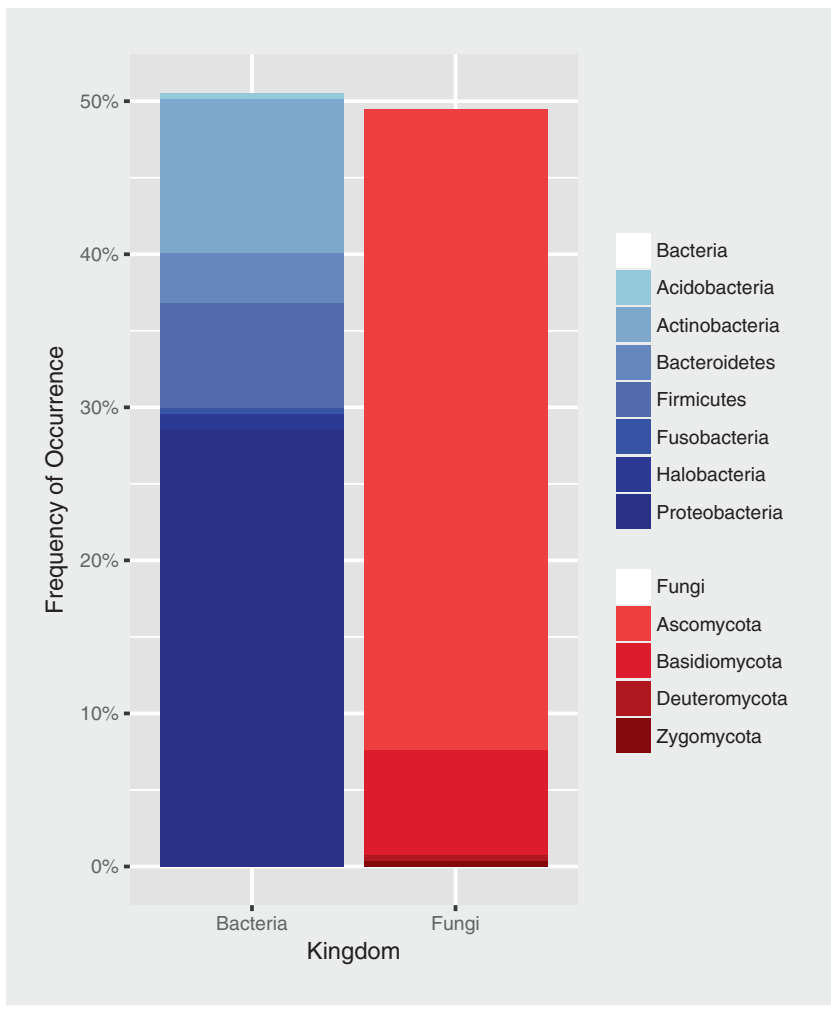

- Fig. 3 The frequency of kingdom and phylum of endophytes isolated in Brazil between the years 2012 and 2017. Bars represent kingdom, and colors represents phylum inside each kingdom.

5S, Supporting Information). The dentification of species within these sections is not possible using only ITS sequences [42,43].

Chagas et al. [35] and Conti et al. [33] identified seven isolates belonging to the genus Streptomyces based on the 16S rRNA partial sequence $(\sim 400 \mathrm{bp})$. The authors performed the phylogenic analysis using only a few species of the more than 500 species belonging to the genus Streptomyces. In addition to the low number of species used for phylogenetic analyses, in some cases, the isolate presented $100 \%$ similarity with more than one species, such as the strain RLe13. In these cases, the authors identified the strain as belonging to the species based on the similarity to the sequence of species deposited in the CBS database, even without phylogenetic support. Several authors have reported the low discriminatory power of ribosomal markers and have suggested a minimum of four loci to identify species within the genus Streptomyces $[28,44]$. This same difficulty is observed for fungi, such as the Diaporthe genus, in which few species are identified using only ribosomal markers, such as the ITS sequences ( $\vee$ Table 2 and Figs. $10 \mathrm{~S}$ and 27S, Supporting Information) [25]. In these cases, a multilocus sequences analysis, using protein-coding genes, is recommended $[25,27,41,44]$. Among the protein-coding markers used to identify fungal species, the translation elongation factor 1-alpha (tef1), beta-tubulin (tub2), and actin (act), GAPDH and subunits of RNA polymerase (RPB1 and RPB2) have been commonly used to infer phylogenetic relationships and species identification $[25,44]$. For bacteria, the use of housekeeping genes has 


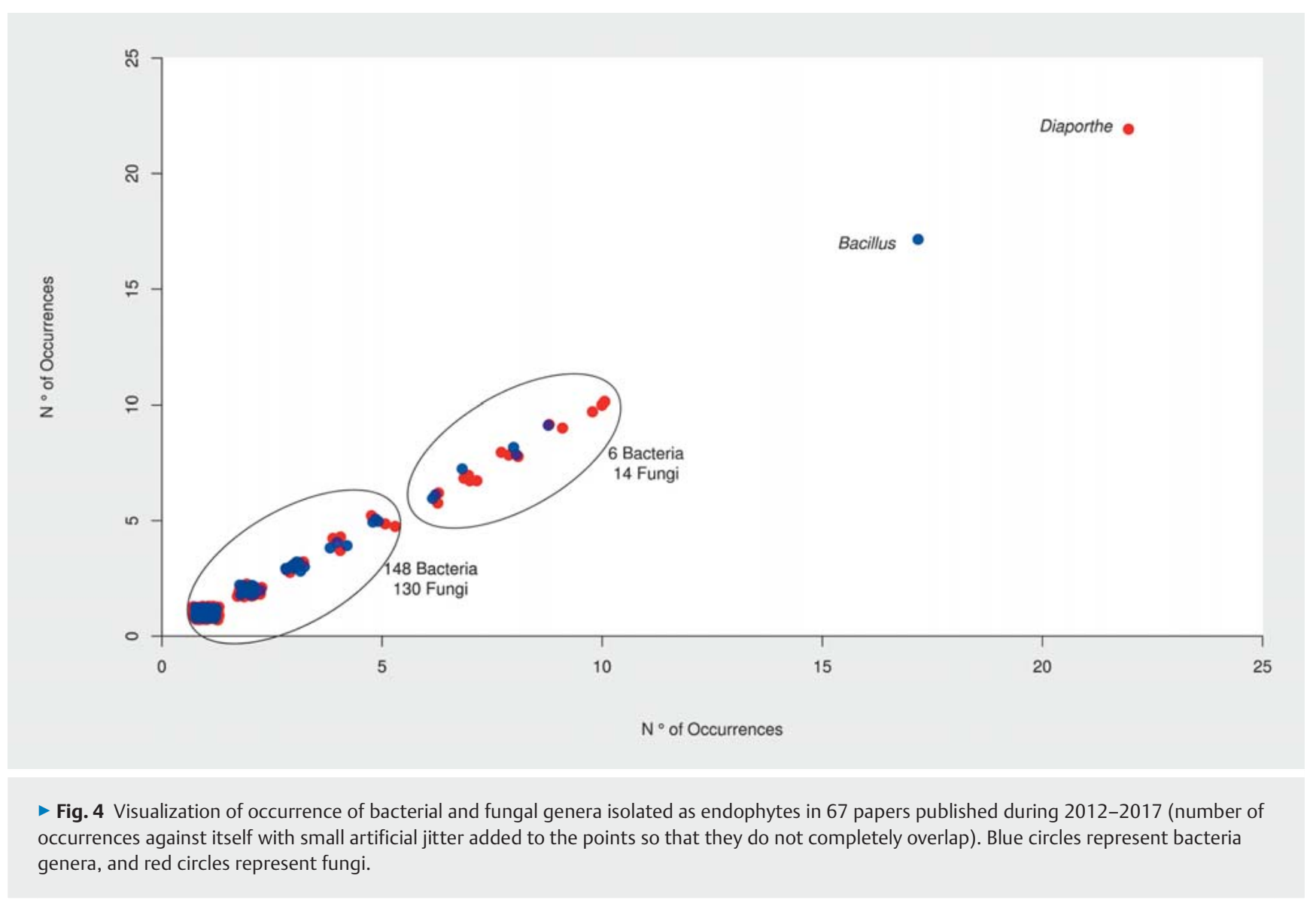

been confirmed as highly reproducible, low cost, and with the same efficiency as DNA-DNA hybridization for species identification. The most common multilocus analysis consists of sequences of gyrB (DNA gyrase, beta subunit), rpoD (RNA polymerase, $\sigma$ factor), recA (recombinase $A$ ), and trpB (tryptophan synthase, beta subunit) genes [27-28, 44, 45].

\section{Biological activity of endophytes found in Brazil}

Research on natural products is still the most effective way to discover new compounds, and less than $10 \%$ of the world's biodiversity has been evaluated for its biological potential [46]. Endophytes have great importance in the production of compounds with a unique structure, which may result from several biological interactions [47], however, the challenge for drug discovery is how to access this chemical potential. Most of the studies on endophytic biodiversity published in Brazil (2012-2017) present some bioprospecting studies, such as evaluation of antibiotic, antioxidant, antiparasitic, or cytotoxicity activities, or the use of endophytes to promote plant growth or reactive dye discoloration $[40,48-54]$ ( $\triangleright$ Table 3 ). As a result of the success obtained in terms of discovering active metabolite-producing endophytes, a large number of compounds [2,55-57] or known compounds with unreported biological properties $[33,36,58-60]$ have been reported.

It is well known that the culture conditions can drastically influence the profile of the metabolites produced by a specific strain.
To evaluate the influence of culture conditions on the antibacterial activity of endophytic isolates of the medicinal plant Schinus terebinthifolius, Tonial et al. [48] explored the production of metabolites using $4 \mathrm{~N}$ (Nitrogen) and $3 \mathrm{C}$ (Carbon) sources, different temperatures, $\mathrm{pH}$, and incubation time. Interestingly, independent of the species analyzed, galactose was the most effective source of carbon to produce active metabolites, acidification provided the best results in terms of activity against Candida albicans, while optimal temperature and nitrogen source varied depending on the strain.

In 2012, Koolen et al. [61] reported for the first time the isolation of cyclo-(glycyl-Ltyrosyl)-4,4-dimethylallyl ether, a diketopiperazine alkaloid, from Gliocladium sp. The compound showed high bactericidal activity against Micrococcus luteus (43.4 $\mu \mathrm{M})$. Diketopiperazine alkaloids are known to possess a broad spectrum of actions exhibiting antibacterial, antifungal, and cytotoxic activities [62].

Andrioli et al. [63] explored the potential of the eugenitin compound, isolated from the endophytic strain Mycoleptodiscus indicus, to increase the production of the enzyme glucoamylase by Aspergillus niveus. Eugenitin increased the activity of $A$. niveus glucoamylase twofold, improving the production of glucose and ethanol using starch as a carbon source. The authors explored an unusual biological application to fungal metabolites [64], and their data highlight the importance of understanding the communication between endophytes in the activation of genes related to 


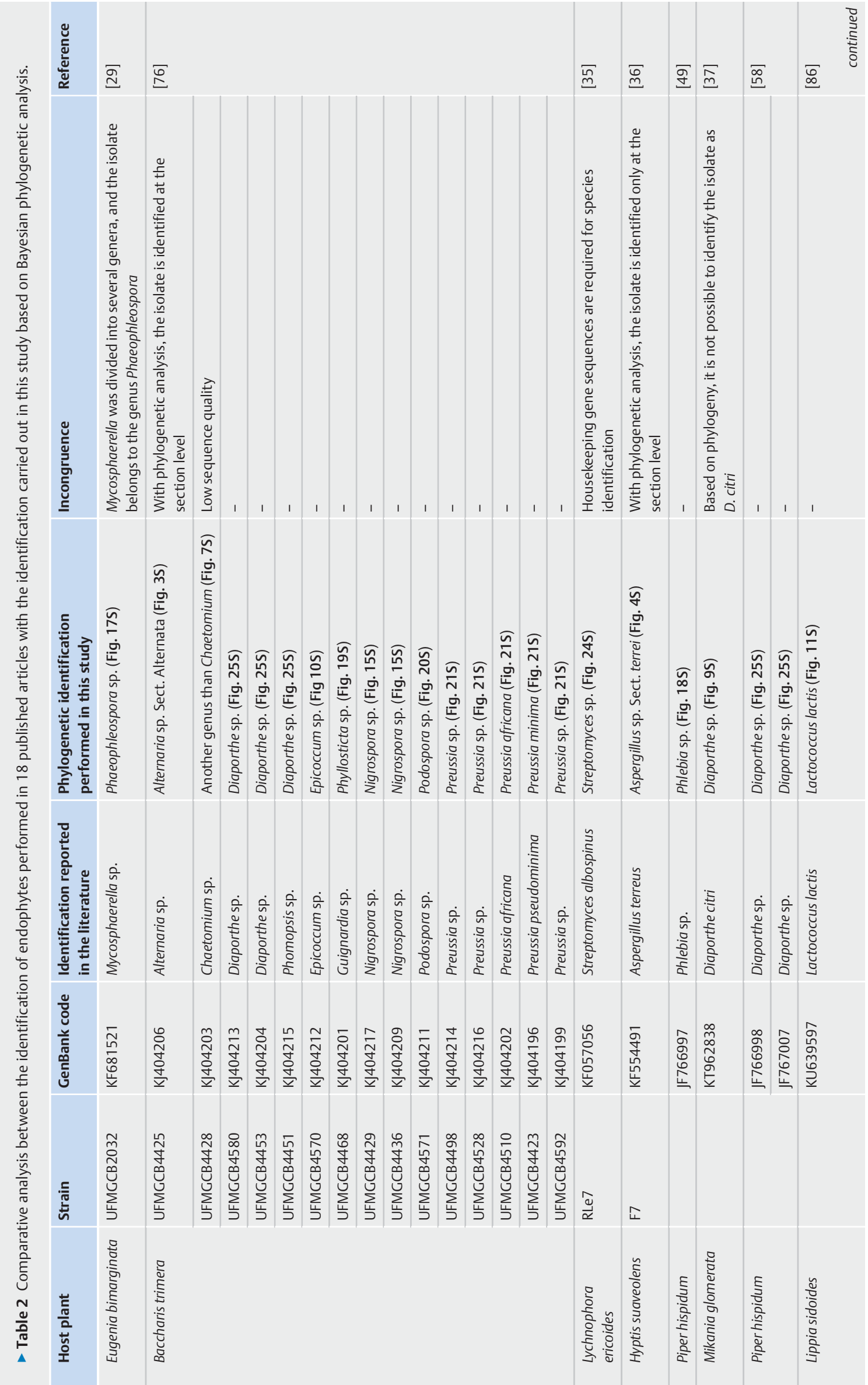




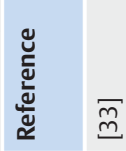

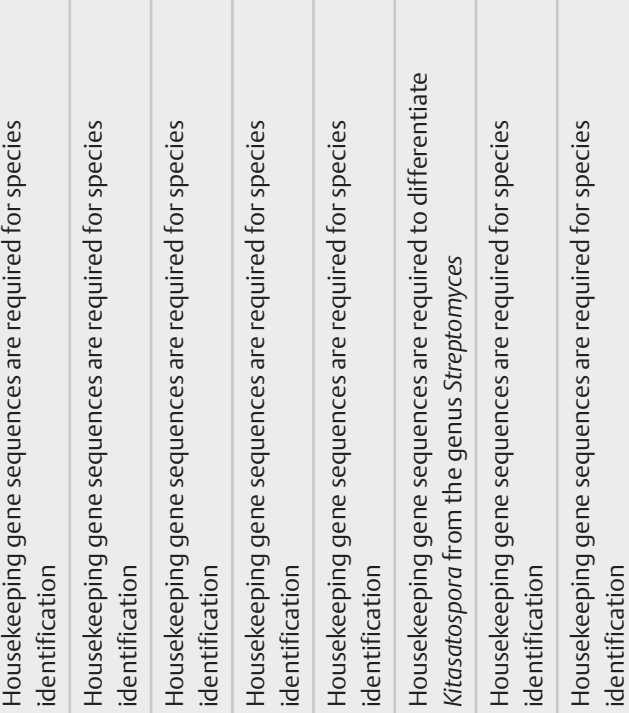

$\stackrel{\infty}{ \pm}$
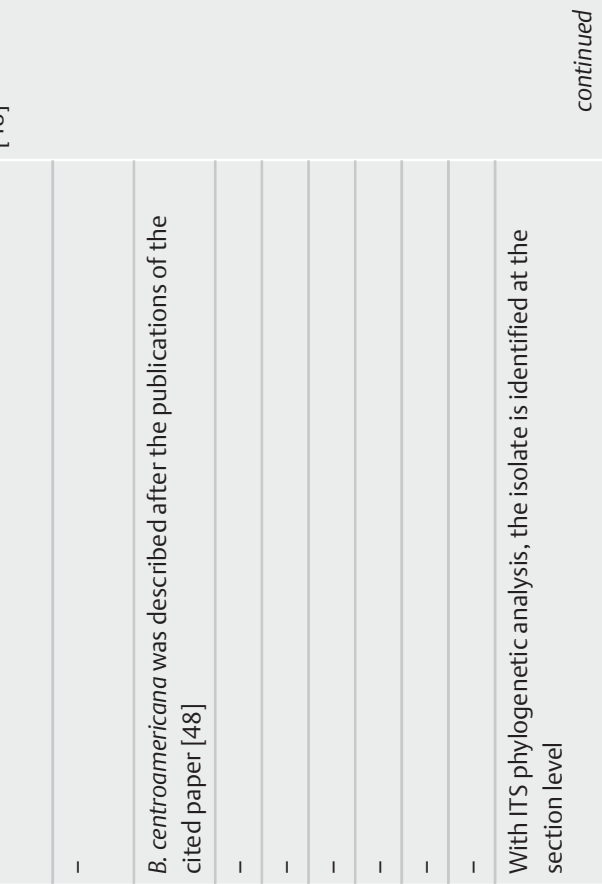

\section{ปั}

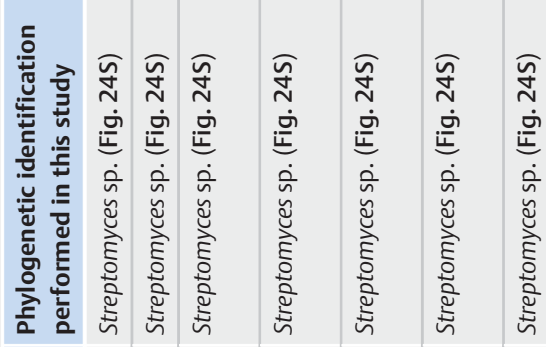

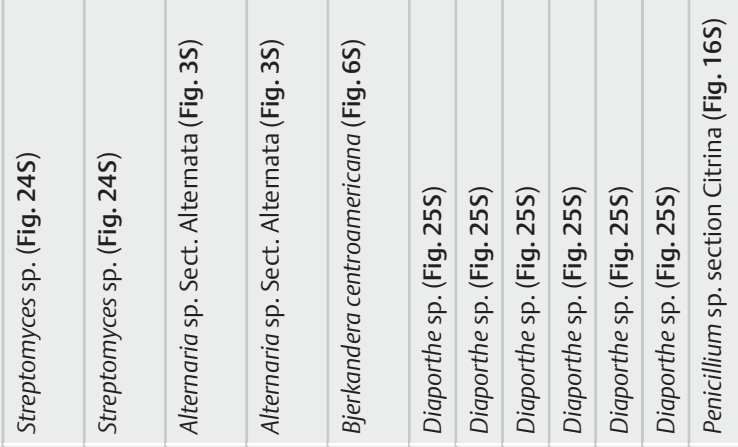

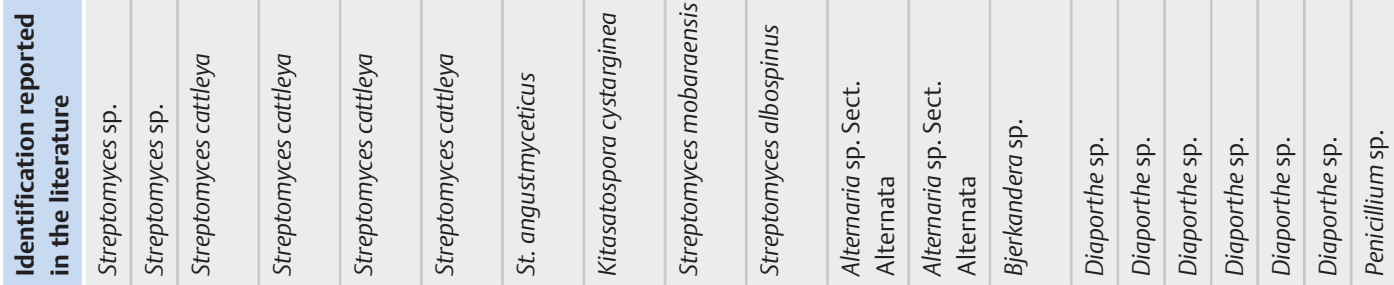

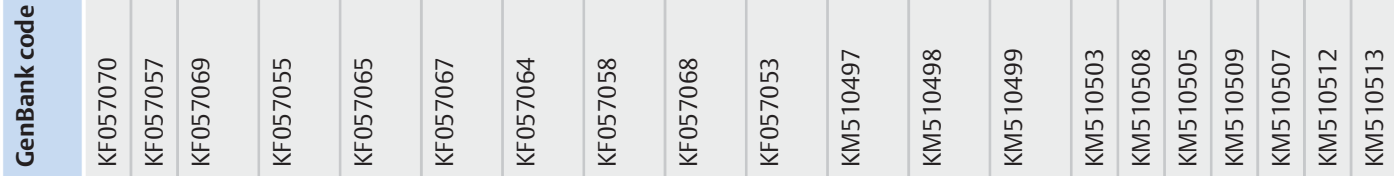

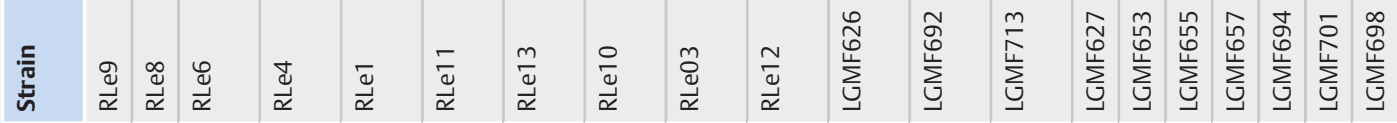



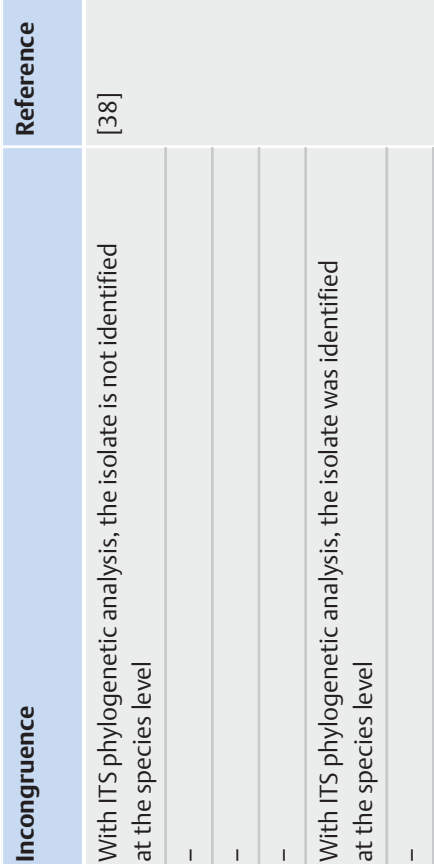

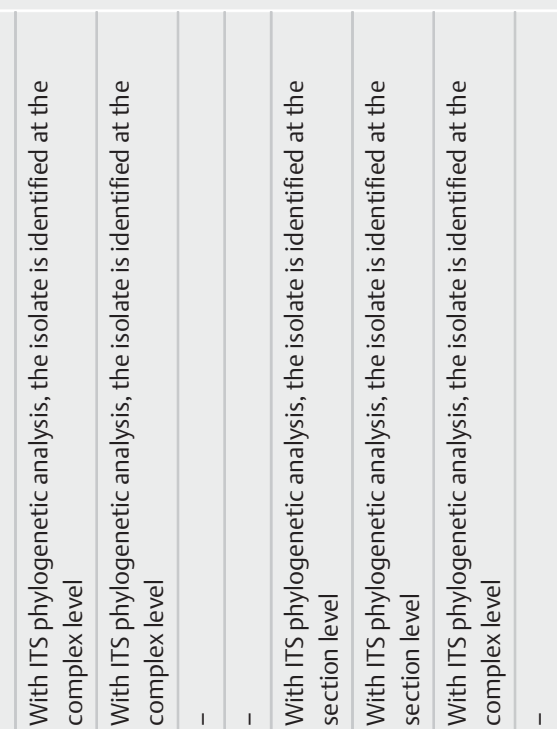

동

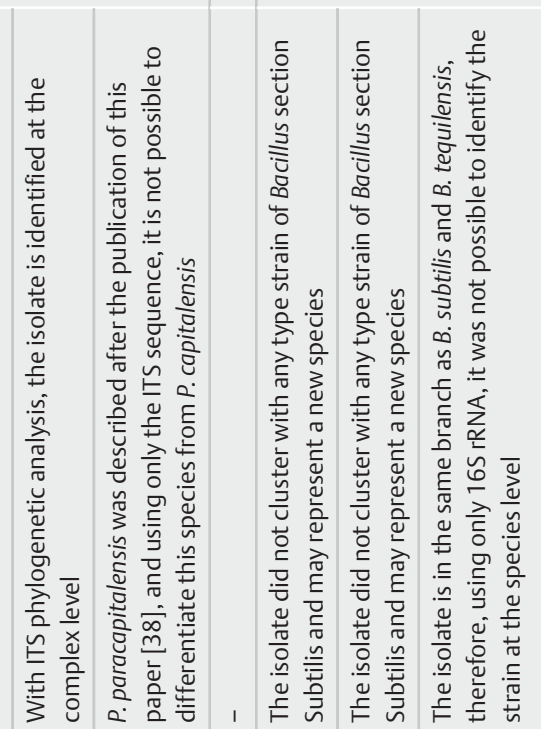

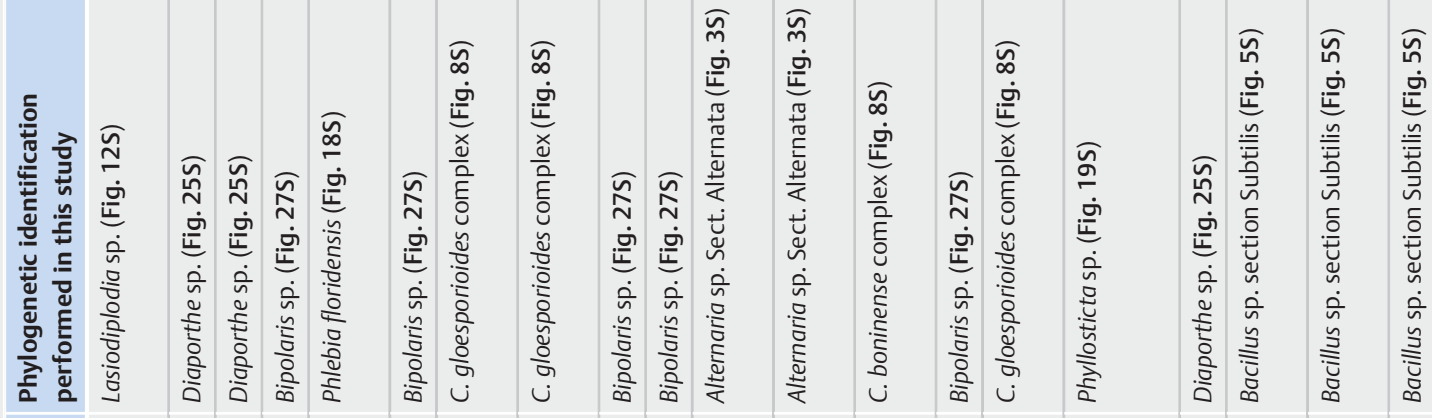
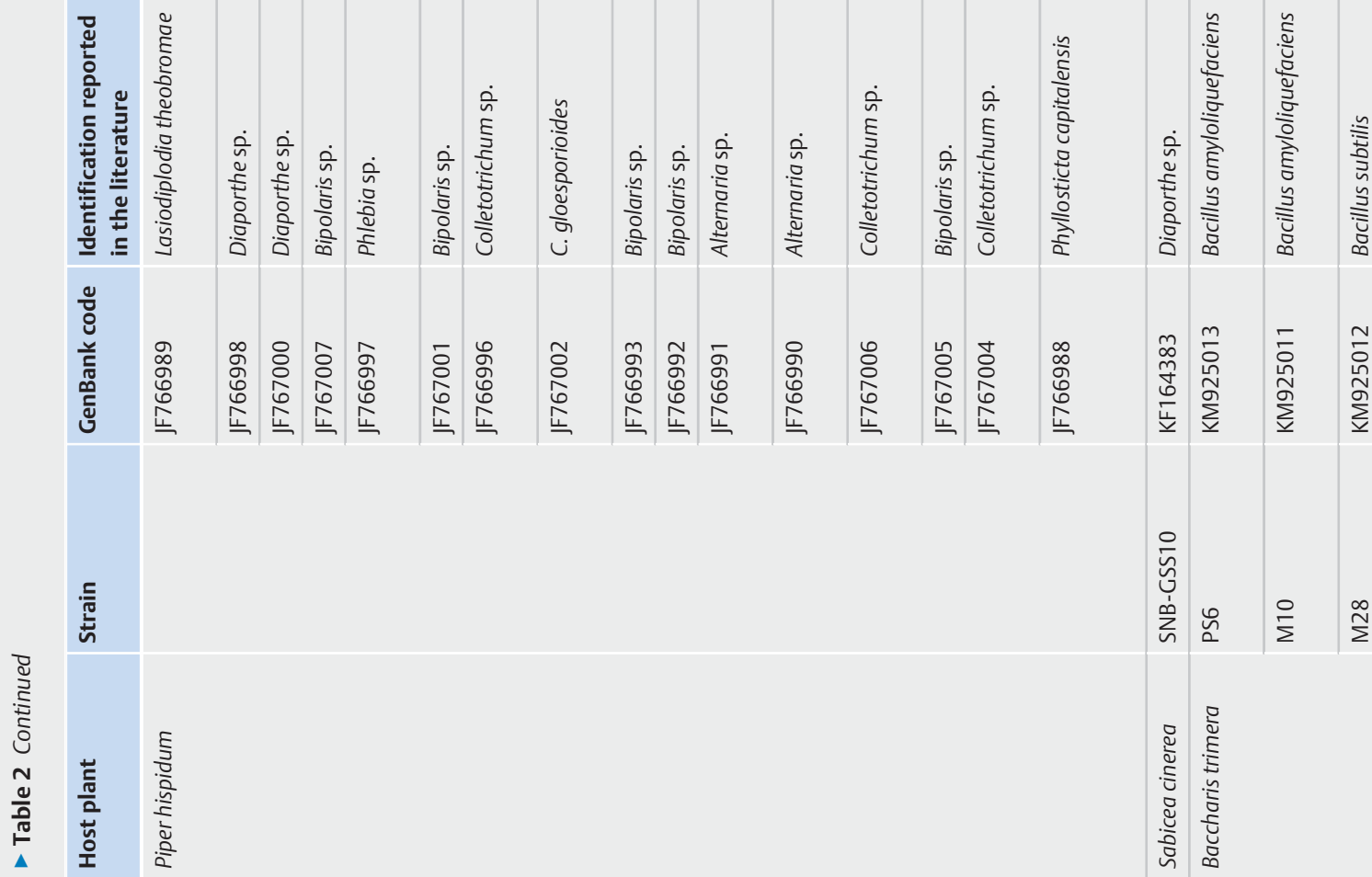


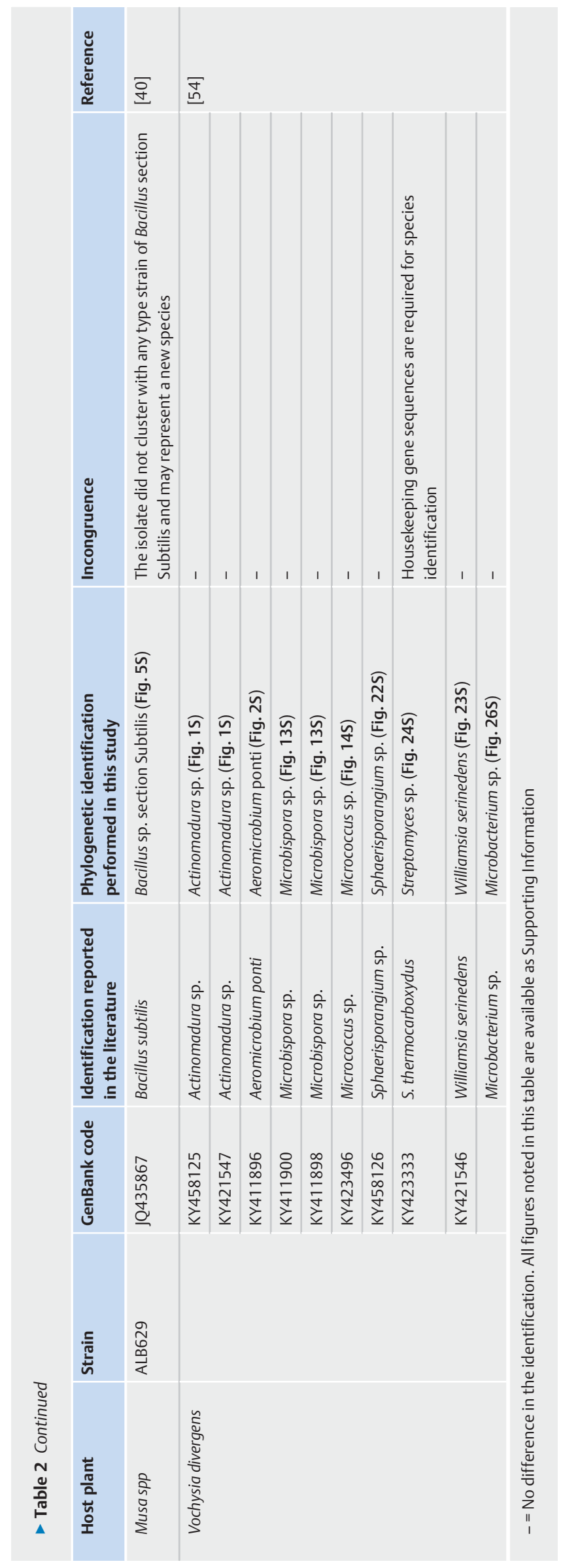




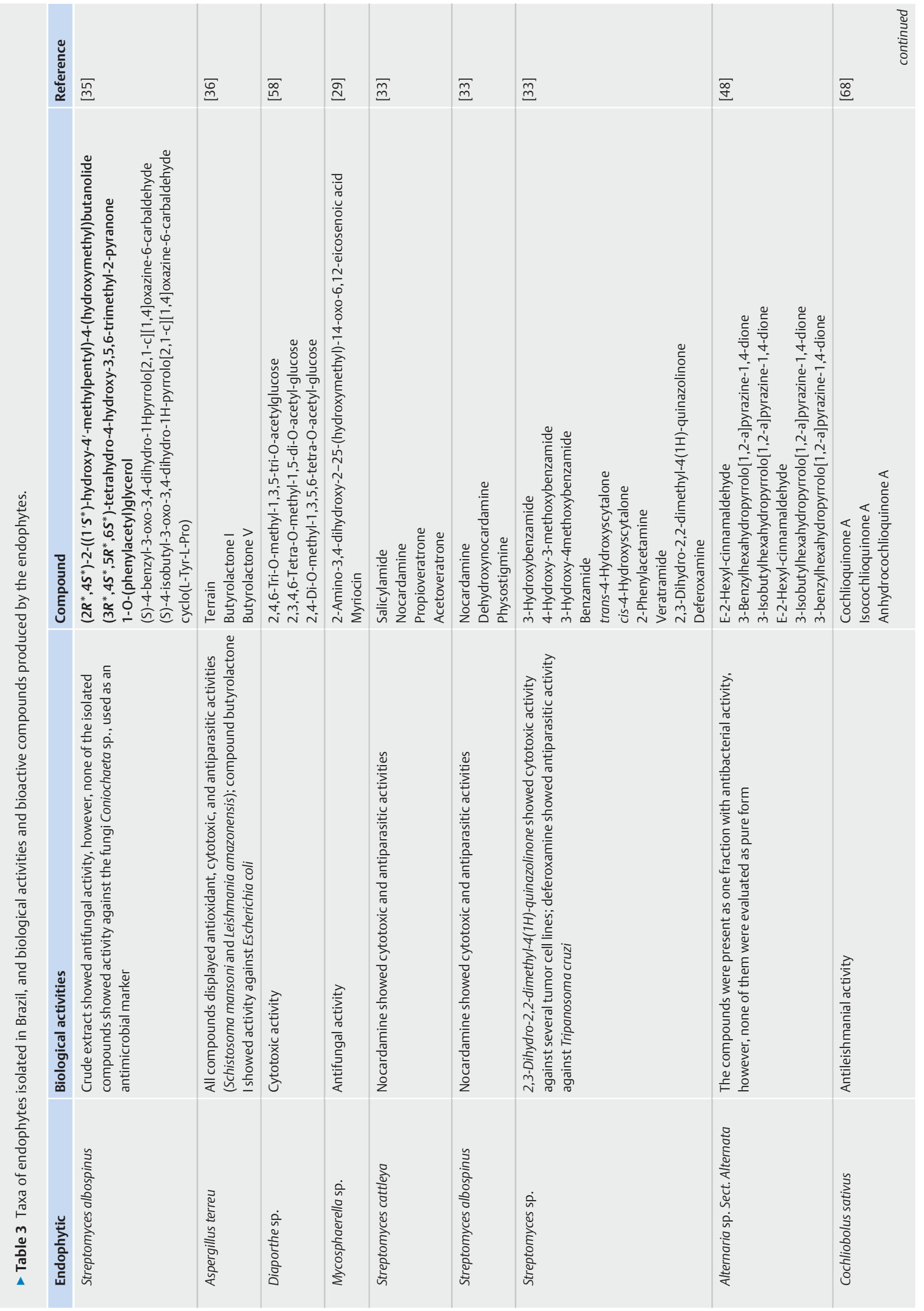




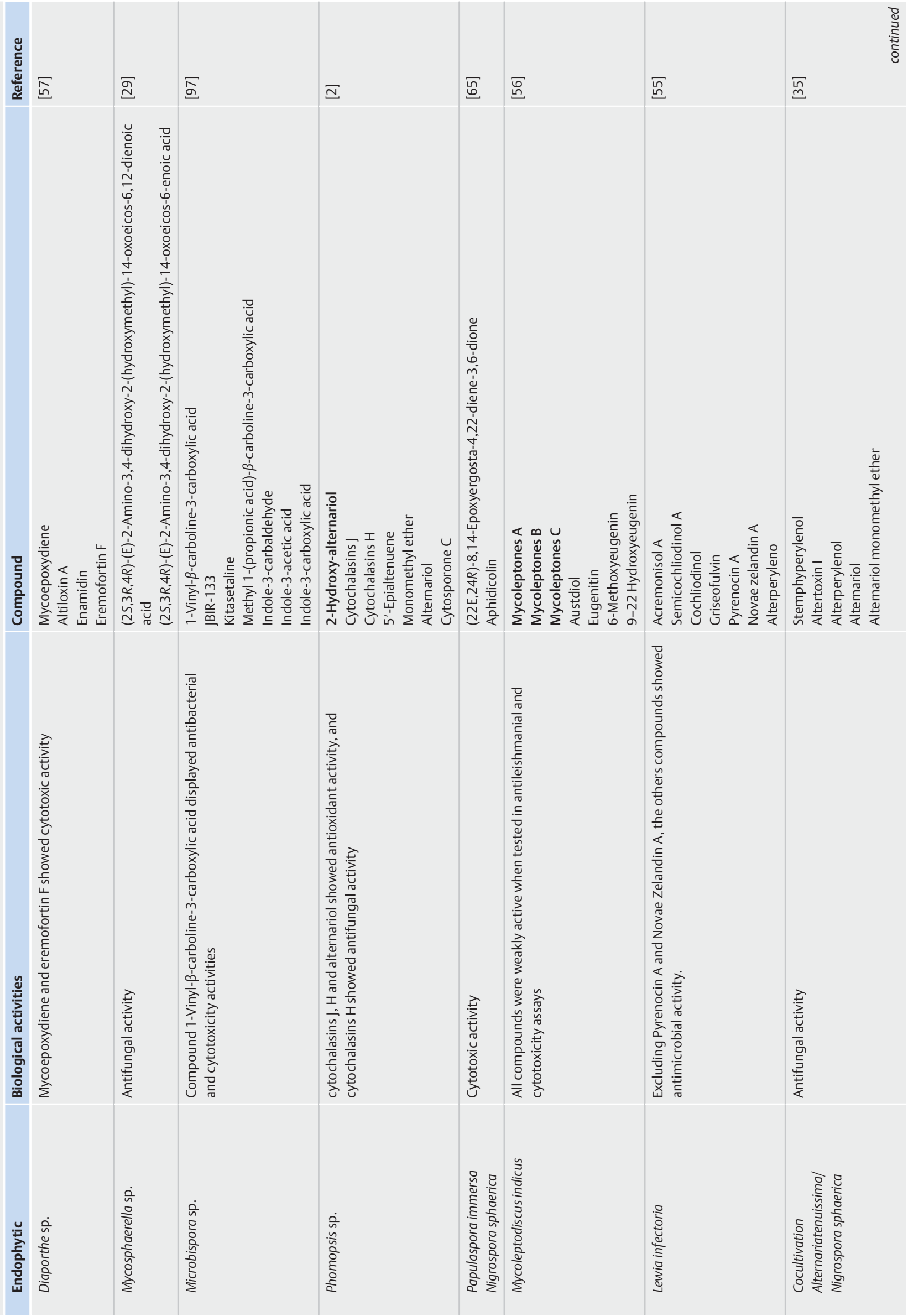




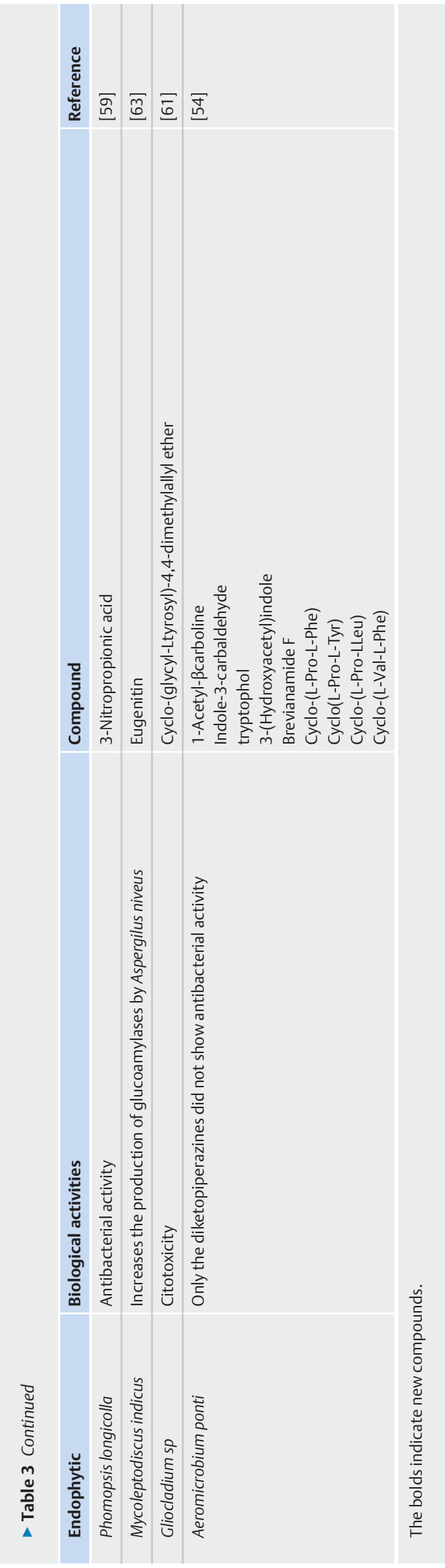

the production of metabolites [3]. In the same aspect, Chagas et al. [35] evaluated the interaction between endophytes of Smallanthus sonchifolius, aiming to understand the chemical communication between Alternaria tenuissima and Nigrospora sphaerica. A. tenuissima produced polyketides with antifungal activity in response to $N$. sphaerica. In addition, the effect of this relationship on the host was also evaluated, and even at concentrations higher than those required for antifungal activity, the compounds did not present phytotoxic activity to the host.

A screening program for the discovery of compounds produced by endophytic fungi from plants belonging to the Asteraceae family resulted in the isolation of two compounds, the steroid $(22 E, 24 R)$-8,14-epoxyergosta-4,22-diene-3,6-dione (a) and the diterpene aphidicolin (b), with strong cytotoxicity against HL60 cells [65]. Compounds (a) and (b) have been reported previously in the literature, however, the mechanism of action in HL60 cells has not been elucidated. Using molecular targets, the authors suggested that compound (a) could influence the $\mathrm{G} 2 / \mathrm{M}$ transition of the mitotic cells cycle, while compound (b) showed apoptotic activity. Since leukemia represents a common type of cancer among adults, and in the United States in 2012 more than 40000 new cases were reported, finding new drugs and understanding how they act against leukemia cells are extremely important discoveries.

Pereira et al. [29] worked with 400 endophytic fungi isolated from different Brazilian ecosystems in order to select active strains against of Cryptococcus neoformans and Cryptococcus gattii. Strain Mycosphaerella sp. UFMGCB 2032, isolated from Eugenia bimarginata, showed remarkable antifungal activity, with MIC values of 31.2 and $7.8 \mu \mathrm{g} / \mathrm{mL}$ against Cryptococcus neoformans and C. gattii, respectively. After several chromatography techniques, two compounds were isolated and identified as responsible for antifungal activity, (2S,3R,4R)-(E)-2-amino-3,4-dihydroxy-2-(hydroxymethyl)-14-oxoeicos-6,12-dienoic acid and (2S,3R,4R)-(E)2-amino-3,4-dihydroxy-2-(hydroxymethyl)-14-oxoeicos-6-enoic acid, against $C$. neoformans and $C$. gattii, with MICs of $1.3-2.50 \mu \mathrm{g} /$ $\mathrm{mL}$ and $0.5 \mu \mathrm{g} / \mathrm{mL}$, respectively. These compounds may represent an option to treat infections caused by Cryptococcus species.

The focus of many studies on natural products is to find compounds with antimicrobial or cytotoxic activities, while the antiparasitic potential remains little explored. Leishmaniasis is an endemic disease in Brazil [66] and is one of the most neglected diseases in the world, affecting poor people in developing countries [67]. In order to find new compounds for the treatment of Leishmaniasis, do Nascimento et al. [68] analyzed 16 endophytic fungi of Vernonia palyanthes. Using a bioassay-guided fractionation of the extract produced by the endophyte Cochliobolus sativus, the compounds cochlioquinone $A$, isocochlioquinone $A$, and anhydrocochlioquinone $A$ were identified as responsible for antileishmanial activity, with $\mathrm{EC}_{50}$ values of $1.7,4.1$, and $50.5 \mu \mathrm{g} / \mathrm{mL}$, respectively.

Seven new compounds have been reported from endophytes found in Brazil in recent years ( $\downarrow$ Table 3 ). The compounds belong to four chemical classes, butanolide ( $\gamma$-lactone, $\delta$-lactone), glyceride (monoacylglycerol) [35], alternariol [2], and azaphilone (mycoleptones) [56] ( $\triangleright$ Table 3). Their chemical structures are listed in $\triangleright$ Fig. 5. The a-d compounds ( $\bullet$ Fig. 5) were isolated in a large 


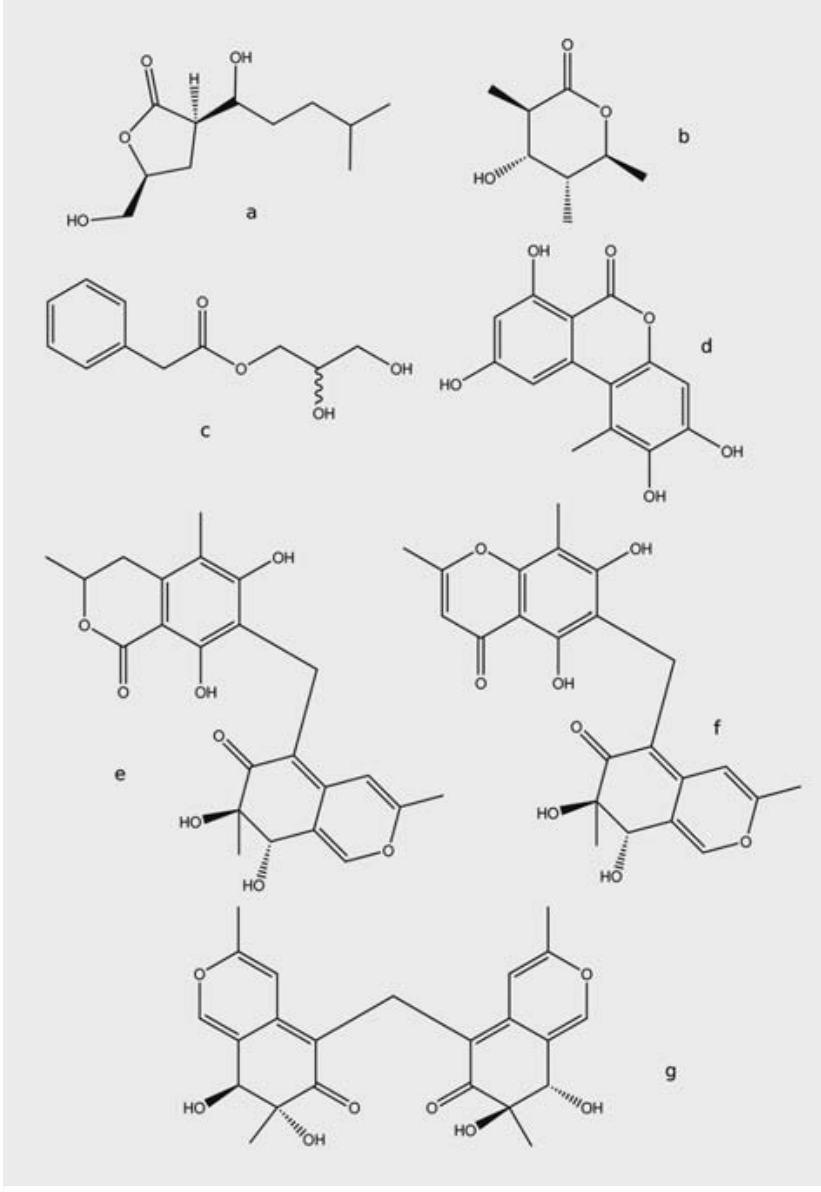

- Fig. 5 Chemical structures of the new compounds isolated from endophytes in Brazil in the years 2012-2017, reported by Chagas et al. [35] (a-c); Chapla et al. [2] (d), and Andrioli et al. [56] (e-g). Chemical structures were obtained using the software Chemdraw (https://chemistry.com.pk/software/chemdraw-free/). amount from the crude extract of endophytes but showed no activity in the biological evaluations [2,35]. The absence of activity under laboratory conditions may not necessarily reflect the role of these metabolites in nature. Knowledge of biological functions in the interaction of microbes with the environment can provide insight into how these molecules are used by the microorganism [69]. The mycoleptones ( $\bullet$ Fig. $\mathbf{5 e - g}$ ) are azophilones with an unusual methylene bridge and were produced by the endophytic strain $M$. indicus isolated from the medicinal plant Borreria verticillata. Azaphilones are known for their range of biological activity, such as antimicrobial, nematicidal, and anti-inflammatory [70]. Andrioli et al. [56] demonstrated that the new mycoleptones are non-selective compounds with antileishmanial and cytotoxic activities.

Secondary metabolites produced by endophytes, in general, are less toxic to eukaryotes than to prokaryotes, since endophytes should not harm the host plant [17]. This is especially true if we compare the number of compounds with antibacterial activity (16) with those showing antifungal activity (8) ( $\triangleright$ Table 3 ). However, the need for new compounds for the treatment of neglected diseases present in Brazil, such as Leishmaniasis, has led to the development of programs to find metabolites with antiparasitic activity. These programs resulted in the isolation of 17 compounds with antiparasitic activity, the equivalent number of compounds with antibacterial activity ( $\vee$ Table 3 ). The host tolerance to these compounds may be the result of similar molecules produced by the plants, or even the secretion of metabolites that inactivate the toxic metabolites produced by endophytes [6].

\section{Conclusions}

Brazil represents one of the largest biodiversities in the world and most of the biological sources remain underexplored. Between the years 2012-2017, more than 300 genera of fungi and bacteria were identified as endophytes of 54 plant species, with Diaporthe and Bacillus being the most isolated genera. The prevalence of these genera as endophytes may be related to the escape of the host immune response or the production of secondary metabolites that encompass advances in plant resistance to insects and pathogens. Endophytes found in Brazil have been linked as a source of bioactive molecules, some of them with a new molecular structure. Biotechnological advances contribute to enhancing the importance of Brazilian diversity, and new species and bioactive compounds are waiting to be reported.

\section{Supporting information}

Phylogenetic analyzes and compilation data of all species and genera isolated as endophytes from medicinal plants in Brazil from 2012 to 2017 are available as Supporting Information.

\section{Acknowledgements}

D. C. S. thanks the Coordenação de Aperfeiçoamento de Pessoal de Nível Superior (CAPES) for the scholarship.

\section{Conflict of Interest}

The authors declare no conflict of interest.

\section{References}

[1] Siddiqui AA, Iram F, Siddiqui S, Sahu K. Role of natural products in drug discovery process. Int J Drug Dev Res 2014; 6: 172-204

[2] Chapla VM, Zeraik ML, Ximenes VF, Zanardi LM, Lopes MN, Cavalheiro A], Silva DHS, Young MCM, Fonseca LM, Bolzani VS, Araújo AR. Bioactive secondary metabolites from Phomopsis sp., an endophytic fungus from Senna spectabilis. Molecules 2014; 19: 6597-6608

[3] Gouda S, Das G, Sen SK, Shin HS, Patra JK. Endophytes: a treasure house of bioactive compounds of medicinal importance. Front Microbiol 2016; 7: 1538

[4] Deepika VB, Murali TS, Satyamoorthy K. Modulation of genetic clusters for synthesis of bioactive molecules in fungal endophytes: A review. Microbiol Res 2016; 182: 125-140

[5] Stierle AA, Stierle DB. Bioactive secondary metabolites produced by the fungal endophytes of conifers. Nat Prod Commun 2015; 10: 1671-1682

[6] Brader G, Compat S, Vescio K, Mitter B, Trognitz F, Ma L], Sessitsch A. Insights into plant-pathogenic and plant-nonpathogenic endophytes. Annu Rev Phytopathol 2017; 55: 61-83 
[7] Brazil Flora Group (BFG). Growing knowledge: an overview of seed plant diversity in Brazil. Rodriguésia 2015; 66: 1085-1113

[8] De Bary A. Morphologie und Physiologie der Pilze, Flechten und Myxomyceten. Handbuch der physiologischen Botanik. 2. Band. Leipzig: Wilhelm Engelmann; 1866: 1831-1888

[9] Petrini O. Fungal Endophytes of Tree Leaves. In: Andrews ], Hirano S, eds. Microbial Ecology of Leaves. New York: Springer; 1991

[10] Hardoin PR, van Overbeek LS, Berg G, Pirttila AM, Compant S, Campisano A, Doring M, Sessitsch A. The hidden world within plants: ecological and evolutionary considerations for defining functioning of microbial endophytes. Microbil Mol Biol Rev 2015; 79: 293-320

[11] Kandel SL, Joubert PM, Doty S. Bacterial endophytes colonization and distribution within plants. Microorganisms 2017; 5: E77

[12] Venieraki A, Dimou M, Katinakis P. Endophytic fungi residing in medicinal plants have the ability to produce the same or similar pharmacologically active secondary metabolites as their hosts. Hellenic Plant Prot J 2017; 10: 51-66

[13] Santoyo G, Moreno-Hagelsieb G, Orozco-Mosqueda MDC, Glick B. Plant growth-promoting bacterial endophytes. Microbiol Res 2016; 183: $92-$ 99

[14] Pusztahelyi T, Holb IJ, Pócsi I. Secondary metabolites in fungus-plant interactions. Front Plant Sci 2015; 6: 573

[15] Ghini R, Hamada E, Bettiol W. Climate change and plant diseases. Sci Agric 2008; 65: 98-107

[16] Myers N, Mittermeier RA, Mittermeier CG, Fonseca GAB, Kent ]. Biodiversity hotspots for conservation priorities. Nature 2000; 403: 853-858

[17] Martinez-Klimova E, Rodríguez-Peña K, Sánchez S. Endophytes as sources of antibiotics. Biochem Pharmacol 2017; 134: 1-17

[18] El-Deeb B, Fayeza K, Gherbawya Y. Isolation and characterization of endophytic bacteria from Plectranthus tenuiflorus medicinal plant in Saudi Arabia desert and their antimicrobial activities. J Plant Interact 2013; 8: 56-64

[19] Ferreira MC, Vieira MLA, Zani CL, Alves TMA, Junior PAS, Murta SMF, Romanha AJ, Gil LHVG, Carvalho AGO, Zilli JE, Vital MJS, Rosa CA, Rosa LH. Molecular phylogeny, diversity, symbiosis and discover of bioactive compounds of endophytic fungi associated with the medicinal Amazonian plant Carapa guianensis Aublet (Meliaceae). Biochm Syst Ecol 2015; 59: $36-44$

[20] Santos PJC, Savi DC, Gomes RR, Goulin EH, Senkiv CC, Tanaka FAO, Almeida AMR, Galli-Terasawa L, Kava V, Glienke C. Diaporthe endophytica and $D$. terebinthifolii from medicinal plants for biological control of Phyllosticta citricarpa. Microbiol Res 2016; 186: 153-160

[21] Nicoletti R, Fiorentino A. Plant bioactive metabolites and drug produced by endophytic fungi of Spermatophyta. Agriculture 2015; 5: 918-970

[22] Tahir HAS, Gu Q, Wu H, Niu Y, Huo R, Gao X. Bacillus volatiles adversely affect the physiology and ultra-structure of Ralstonia solanacearum and induce systemic resistance in tobacco against bacterial wilt. Sci Rep 2017; 7: 40481

[23] Raja HA, Miller NA, Pearce C], Oberlies NH. Fungal identification using molecular tools: a primer for the natural products research community. J Nat Prod 2017; 80: 756-770

[24] Selim KA, El-Beih AA, Abdel-Rahman TM, El-Diwany Al. Biology of endophytic fungi. Cur Res Env App Myc 2012; 2: 31-82

[25] Gomes RR, Glienke C, Videira SIR, Lombard L, Groenewald JZ, Crous PW. Diaporthe: a genus of endophytic, saprobic and plant pathogenic fungi. Persoonia 2013; 31: 1-41

[26] Chitrampalam P, Nelson B jr. Multilocus phylogeny reveals an association of agriculturally important Fusarium solani species complex (FSSC) 11, and clinically important FSSC 5 and FSSC 3 + 4 soybean roots in the north central United States. Antonie Van Leeuwenhoek 2016; 109: 335-347
[27] Savi DC, Aluizio R, Galli-Terasawa L, Kava V, Glienke C. 16S-gyrB-rpoB multilocus sequence analysis for species identification in the genus Microbispora. Antonie Van Leeuwenhoek 2016; 109: 801-815

[28] Guo Y, Zheng W, Rong X, Huang Y. A multilocus phylogeny of the Streptomyces griseus 16S rRNA gene clade: use of multilocus sequence analysis for streptomycete systematics. Int J Syst Evol Microbiol 2008; 58: 149-159

[29] Pereira CB, Oliveira DM, Hughes AFS, Kohlhoff M, Vieira MLA, Vaz ABM, Ferreira MC, Carvalho CR, Rosa LH, Rosa CA, Alves TMA, Zani CL, Johann $S$, Cota BB. Endophytic fungal compounds active against Cryptococcus neoformans and C. gattii. J Antiob 2015; 1: 1-9

[30] Crous PW. Mycosphaerella spp. and their anamorphs associated with leaf spot diseases of Eucalyptus. Mycol Memoir 1998; 21: 1-170

[31] Crous PW, Hong L, Wingfield BD, Wingfield MJ. ITS rDNA phylogeny of selected Mycosphaerella species and their anamorphs occurring on Myrtaceae. Mycol Res 2001; 105: 425-431

[32] Vieira MLA, Hughes AFS, Gil VB, Vaz ABM, Alves TMA, Zani CL, Rosa CA Rosa LH. Diversity and antimicrobial activities of the fungal endophyte community associated with the traditional Brazilian medicinal plant Solanum cernuum Vell. (Solanaceae). Can J Microbiol 2012; 58: 54-66

[33] Conti R, Chagas FO, Caraballo-Rodriguez AM, Melo WGP, Nascimento AM, Cavalcanti BC, Moraes MO, Pessoa C, Costa-Lotufo LV, Krogh R, Adricopulo AD, Lopes NP, Pupo MT. Endophytic actinobacteria from the Brazilian medicinal plant Lychnophora ericoides Mart. and the biological potential of their secondary metabolites. Chem Biodiversity 2016; 13: 727-736

[34] Wellington EM, Stackebrandt E, Sanders D, Wolstrup J, Jorgenses NO. Taxonomic status of Kitasatospora, and proposed unification with Streptomyces on the basis of phenotypic and 16S rRNA analysis and emendation of Streptomyces. Int J Syst Bacteriol 1992; 42: 156-160

[35] Chagas FO, Caraballo-Rodrígues AM, Dorrestein PC, Pupo MT. Expanding the chemical repertoire of the endophyte Streptomyces albospinus RLe7 reveals amphotericin B as an inducer of a fungal phenotype. J Nat Prod 2017; 80: 1302-1309

[36] Silva IP, Brissow E, Kellner Filho LC, Senabio J, da Siqueira KA, Vandresen Filho S, Damasceno JL, Mendes AS, Tavares DC, Magalhães LG, Junior PA, Januário AH, Soares MA. Bioactive compounds of Aspergillus terreus-F7, an endophytic fungus from Hyptis suaveolens (L.) Poit. World J Microbiol Biotechnol 2017; 33: 62-67

[37] Polonio JC, Ribeiro MAS, Rhoden AS, Sarragiotto MH, Azevedo JL, Pamphile JA. 3-Nitropropionic acid production by the endophytic Diaporthe citri: molecular taxonomy, chemical characterization, and quantification under pH variation. Fungal Biol 2016; 120: 1600-1608

[38] Orlandelli RC, Almeida TT, Alberto RN, Polonio JC, Azevedo JL, Pamphile JA. Antifungal and proteolytic activities of endophytic fungi isolated from Piper hispium Sw. Braz J Microbiol 2015; 46: 359-366

[39] Souza A, Cruz JC, Sousa NR, Procópio ARL, Silva GF. Endophytic bacteria from banana cultivars and their antifungal activity. Genet Mol Res 2014; 13: $8661-8670$

[40] Falcão LL, Silva-Werneck JO, Vilarinho BR, Silva JP, Pomella AWV Marcellino LH. Antimicrobial and plant growth-promoting properties of the cacao endophyte Bacillus subtilis ALB629. App Microbiol 2014; 116: 1584-1592

[41] Guarnaccia V, Groenewald JZ, Li H, Glienke C, Carstens E, Hattingh V, Fourie PH, Crous PW. First report of Phyllosticta citricarpa and description of two new species, $P$. paracapitalensis and $P$. paracitricarpa, from citrus in Europe. Stud Mycol 2017; 87: 161-185

[42] Samson RA, Visagie CM, Houbraken J, Hong SB, Hubka V, Klaassen CHW, Perrone G, Seifert KA, Susca A, Tanney JB, Varga J, Kocsub S, Szigeti G, Yaguchi T, Frisvad JC. Phylogeny, identification and nomenclature of the genus Aspergillus. Stud Mycol 2014; 78: 141-173

[43] Bhandari V, Ahmod NZ, Shah HN, Gupta RS. Molecular signatures for Bacillus species: demarcation of the Bacillus subtilis and Bacillus cereus clades in molecular terms and proposal to limit the placement of new 
species into the genus Bacillus. Int J Syst Evol Microbiol 2013; 63: 2712 2726

[44] Labeda DP, Doroghazi JR, Ju KS, Metcaf WW. Taxonomic evaluation of Streptomyces albus and related species using multilocus sequence analysis and proposals to emend the description of Streptomyces albus and describe Streptomyces pathocidini sp. nov. Int J Syst Evol Microbiol 2014; 64: 894-900

[45] Zhan XY, Zhu QY. Molecular typing of Legionella pneumophila isolates from environmental water samples and clinical samples using a fivegene sequence typing and standard sequence-based typing. PLoS One 2018; 13: e0190986

[46] Xie T, Song S, Li S, Ouyang L, Xia L, Huang J. Review of natural products databases. Cell Prolif 2015; 48: 398-404

[47] Hong J. Natural product diversity and its role in chemical biology and drug discovery. Curr Opin Chem Biol 2011; 15: 350-354

[48] Tonial F, Maia BHLNS, Gomes-Figueiredo JA, Sobottka AM, Bertol CD, Nepel A, Savi DC, Vicente VA, Gomes RR, Glienke C. Influence of culturing conditions on bioprospecting and the antimicrobial potential of endophytic fungi from Schinus terebinthifolius. Curr Microbiol 2015; 72: 173-183

[49] Bulla LMC, Polonio JC, Portela-Castro ALB, Kava V, Azevedo JL, Pamphile JA. Activity of the endophytic fungi Phlebia sp. and Paecilomyces formosus in decolourisation and the reduction of reactive dyes' cytotoxicity in fish erythrocytes. Environ Monit Assess 2017; 88: 1-10

[50] Silva K], Armas RD, Soares CR, Ogliari JB. Communities of endophytic microorganisms in different developmental stages from a local variety as well as transgenic and conventional isogenic hybrids of maize. World J Microbiol Biotechnol 2016; $32: 189$

[51] Santos TT, Leite TS, Queiroz CB, Araujo EF, Pereira OL, Queiroz MV. High genetic variability in endophytic fungi from the genus Diaporthe isolated from common bean (Phaseolus vulgaris L.) in Brazil. J App Microbiol 2016; 120: 388-401

[52] dos Santos SG, da Silva PRA, Garcia AC, Zilli JE, Berbara RLL. Dark septate endophyte decreases stress on rice plants. Braz J Microbiol 2017; 48: 333-341

[53] Silva MCS, Polonio JC, Quecine MC, Almeida TT, Bogas AC, Pamphile JA, Pereira JO, Astolfi-Filho S, Azevedo JL. Endophytic cultivable bacterial community obtained from the Paullinia cupana seed in Amazonas and Bahia regions and its antagonistic effects against Colletotrichum gloeosporioides. Microb Pathog 2016; 98: 16-22

[54] Gos FMR, Savi DC, Shaaban KA, Thorson JS, Aluizio R, Possiede YM, Rohr J, Glienke C. Antibacterial activity of endophytic actinomycetes isolated from the medicinal plant Vochysia divergens (Pantanal, Brazil). Front Microbiol 2017; 8: 1642

[55] Casella TM, Eparvier V, Mandavid H, Bendelac A, Odonne G, Dayan L, Duplais C, Espndola LS, Stien D. Antimicrobial and cytotoxic secondary metabolites from tropical leaf endophytes. Phytochem 2013; 96: 370377

[56] Andrioli W], Conti R, Araújo M], Zanasi R, Cavalcanti BC, Manfrim V, Toledo JS, Tedesco D, Moraes MO, Pessoa C, Cruz AK, Bertucci C, Sabino J, Nanayakkara DNP, Pupo MT, Bastos JK. Mycoleptones A-C and polyketides from the endophyte Mycoleptodiscus indicus. J Nat Prod 2013; 77: 70-78

[57] Mandavid H, Rodrigues AMS, Espindola LS, Eparvier V, Stien D. Secondary metabolites isolated from the Amazonian endophytic fungus Diaporthe sp. SNB-GSS10. J Nat Prod 2015; 78: 1735-1739

[58] Orlandelli RC, da Silva MLC, Vasconcelos AFD, Almeida IV, Vicentini VEP, Prieto A, Hernandez MDD, Azevedo JL, Pamphile JA. $\beta$-(1-3,1-6)-D-glucans produced by Diaporthe sp. endophytes: purification, chemical characterization and antiproliferative activity against MCF-7 and HepC2-C3A cells. Int J Biol Macromol 2017; 94: 431-437

[59] Flores AC, Pamphile JA, Sarragiotto MH, Clemente E. Production of 3-nitropropionic acid by endophytic fungus Phomopsis longicolla isolated from Trichilia elegans A. JUSS ssp. elegans and evaluation of biological activity. World J Microbiol Biotechnol 2013; 29: 923-932

[60] Sebastianes FLS, Cabedo N, El Aouad N, Valente AM, Lacava PT, Azevedo JL, Pizzirani-Kleiner AA, Cortes D. 3-Hydroxypropionic acid as an antibacterial agent from endophytic fungi Diaporthe phaseolorum. Curr Microbiol 2012; 65: 622-632

[61] Koolen HHF, Soares ER, Silva FMA, Souza AQL, Medeiros LS, Filho ER, Almeida RA, Ribeiro IA, Pessoa CO, Morais MO, Costa PM, Souza ADL. An antimicrobial diketopiperazine alkaloid and co-metabolites from an endophytic strain of Gliocladium isolated from Strychnos cf. toxifera. Nat Prod Res 2012; 26: 2013-2019

[62] Netz N, Opatz T. Marine indole alkaloids. Mar Drug 2015; 13: 48144914

[63] Andrioli W], Silva TM, Silva VB, Damásio ARL, Maller A, Conti R, Jorge JA, Araújo JM, Silva CHTP, Pupo MT, Polizeli MLTM, Bastos JK. The fungal metabolite eugenitin as additive for Aspergillus niveus glucoamylase activation. J Mol Cat 2012; 74: 156-161

[64] Tanimura A, Kikukawa M, Yamaguchi S, Kishino S, Ogawa J, Shima J. Direct ethanol production from starch using a natural isolate, Scheffersomyces shehatae: toward consolidated bioprocessing. Sci Rep 2015; 5: 9593

[65] Gallo MBC, Falso MJS, Balem F, Menezes D, Rocha N, Balachandran R, Sturgeon TS, Pupo MT, Day BW. The anti-promyelocytic leukemia mode of action of two endophytic secondary metabolites unveiled by a proteomic approach. Planta Med 2014; 80: 473-481

[66] Pacheco SJB, Araujo-Melo MH, Valete-Rosalino CM, Pimentel MIF, Conceição-Silva F, Schubach AO, Marzochi MCA. Endemic tegumentary Leishmaniasis in Brazil: correlation between level of endemicity and number of cases of mucosal disease. Ann J Trop Med Hyg 2012; 84: 901-905

[67] Pinto EG, Santos IO, Schmidt T], Borborema SET, Ferreira VF, Rocha DR, Tempone AG. Potential of 2-hydroxy-3-phenylsulfanylmethyl-[1,4]naphthoquinones against Leishmania (L.) infantum: biological activity and structure-activity relationships. PLoS One 2014; 9: e105127

[68] do Nascimento AM, Soares MG, da Silva Torchelsen FK, de Araujo JA Lage PS, Duarte MC, Andrade PH, Ribeiro TG, Coelho EA, do Nascimento AM. Antileishmanial activity of compounds produced by endophytic fungi derived from medicinal plant Vernonia polyanthes and their potential as source of bioactive substances. World J Microbiol Biotechnol 2015; 31: 1793-1800

[69] Davies ], Ryan KS. Introducing the parvome: bioactive compounds in the microbial world. Chem Biol 2012; 7: 252-259

[70] Osmanova N, Schultze W, Ayoub N. Azaphilones: a class of fungal metabolites with diverse biological activities. Phytochem Rev 2010; 9: 315-342

[71] Oliveira SF, Bocayuva MF, Veloso TGR, Bazzolli DMS, Cynthia CS, Pereira OL, Kasuya MCM. Endophytic and mycorrhizal fungi associated with roots of endangered native orchids from the Atlantic Forest, Brazil. Mycorrhiza 2013; 24: 55-64

[72] Almeida Trapp M, De Souza GD, Rodrigues-Filho E, Boland W, Mithofer A. Validated method for phytohormone quantification in plants. Front Plant Sci 2014; 5: 417

[73] Eposito-Polesi NP, de Abreu-Tarazi MF, de Almeida CV, Tsai SM, de Almeida M. Investigation of endophytitic bacterial community in supposedly axenic cultures of pineapple and orchids with evidence on abundant intracellular bacteria. Curr Microbiol 2016; 74: 103-113

[74] Corrado M, Rodrigues KF. Antimicrobial evaluation of fungal extracts produced by endophytic strains of Phomopsis sp. J Basic Microbiol 2004; 44: $157-160$

[75] Castro RA, Quecine MC, Lacava PT, Batista BD, Luvizotto DM, Marcn J, Ferreira A, Melo IS, Azevedo JL. Isolation and enzyme bioprospection of endophytic bacteria associated with plants of Brazilian mangrove ecosystem. Springerplus 2014; 3: 382 
[76] Vieira MLA, Johann S, Hughes FM, Rosa CA, Rosa LH. The diversity and antimicrobial activity of endophytic fungi associated with medicinal plant Baccharis trimera (Asteraceae) from the Brazilian savannah. Can J Microbiol 2014; 60: 847-856

[77] Bezerra JDP, Santos MGS, Svedese VM, Lima DMM, Fernandes MJS, Paiva LM, Souza-Motta CM. Richness of endophytic fungi isolated from Opuntia fícus-indica Mill (Cactaceae) and preliminary screening for enzyme production. World J Microbiol Biotechnol 2012; 28: 1989-1995

[78] Feitosa AO, Dias ACS, Ramos G, Bithencourt HR, Siqueira JES. Lethality of cytochalasin B and other compounds isolated from fungus Aspergillus sp. (Trichocomoceae) endophyte of Bauhinia guianensis (Fabaceae). Rev Argent Microbiol 2016; 48: 259-263

[79] Azevedo JL, Araujo WL, Lacava PT. The diversity of citrus endophytic bacteria and their interactions with Xylella fastidiosa and host plants. Gen Mol Biol 2016; 39: 476-491

[80] Oliveira MNV, Santos TMA, Vale HMM, Delvaux JC, Cordero AP, Ferreira AB, Migues PSB, Totola MR, Costa MD, Moraes CA, Borges AC. Endophytic microbial diversity in coffee cherries of Coffea arabica from southeastern Brazil. Can J Microbiol 2013; 59: 221-230

[81] Almeida TT, Orlandelli RC, Azevedo JL, Pamphile JA. Molecular characterization of the endophytic fungal community associated with Eichhornia azurea (Kunth) and Eichhornia crassipes (Mart.) (Pontederiaceae) native to the upper Paraná river floodplain, Brazil. Genet Mol Res 2015; 14 : 4920-4931

[82] Sposito-Polesi NP, Andrade PAM, Almeida CV, Andreote FD, Almeida M. Endophytic bacterial communities associated with two explant sources of Eucalyptus benthamii Maiden \& Cambage. World J Microbiol Biotechnol 2015; 31: 1737-1746

[83] Miguel PSB, Oliveira MNV, Delvaux JC, Jesus GL, Borges AC, Tótola MR, Neves JCL, Costa MD. Diversity and distribution of the endophytic bacterial community at different stages of Eucalyptus growth. Antonie van Leeuwenhock 2016; 109: 755-771

[84] Pereira GVM, Magalhães KT, Lorenzetii ER, Souza TP, Schwan RF. A multiphasic approach for the identification of endophytic bacterial in strawberry fruit and their potential for plant growth promotion. Microb Ecol 2012; 63: 405-417

[85] Fernandes EG, Pereira OL, Silva CC, Bento CBP, Queiroz MV. Diversity of endophytic fungi in Glycine max. Microbiol Res 2015; 181: 84-92

[86] de Lacerda JRM, Silva TF, Vollú RE, Marques JM, Seldin L. Generally recognized as safe (GRAS) Lactococcus lactis strains associated with Lippia sidoides Cham. are able to solubilize/mineralize phosphate. Springerplus 2016; 5: 828
[87] Bernrdi-Wenzel ], García A, Filho C], Prioli AJ, Pamphile JA. Evaluation of foliar fungal endophyte diversity and colonization of medicinal plant Luehea divaricate (Martius et Zuccarini). Biol Res 2010; 43: 375-384

[88] Banhos EF, Souza AQL, Andrade JC, Souza ADL, Koolen HHF, Albuquerque PM. Endophytic fungi from Myrcia guianensis at the Brazilian Amazon: distribution and bioactivity. Braz J Microbiol 2014; 45: 153-161

[89] Lopes RBM, Costa LEO, Vanetti MCD, Araújo EF, Queiroz MV. Endophytic bacteria isolated from common bean (Phaseolus vulgaris) exhibiting high variability showed antimicrobial activity and quorum sensing inhibition. Curr Microbiol 2015; 71: 509-516

[90] Oliveira ACD, Fernandes ML, Mariano AB. Production and characterization of an extracellular lipase from Candida guilliermondii. Braz J Microbiol 2014; 45: 1503-1511

[91] dos Santos CM, de Souza DG, Balsanelli E, Cruz LM, de Souza EM, Baldani JI, Schwab S. A culture-independent approach to enrich endophytic bacterial cells from sugarcane stems for community characterization. Microb Ecol 2017; 74: 453-465

[92] Rosa LH, Tabanca N, Techen N, Pan Z, Wedge DE, Moraes RM. Antifungal activity of extracts from endophytic fungi associated with Smallanthus maintained in vitro as autotrophic cultures and as pot plants in the greenhouse. Can J Microbiol 2012; 58: 1202-1211

[93] Rhoden AS, Garcia A, Santos e Silva MC, Azevedo JL, Pamphile JA. Phylogenetic analysis of endophytic bacterial isolates from leaves of the medicinal plant Trichilia elegans A. Juss. (Meliaceae). Genet Mol Res 2015; 14: 1515-1525

[94] Lopes MR, Ferreira MC, Carvalho TFC, Pagnocca FC, Chagas RA, Morais PB, Rosa LH, Lachance MA, Rosa CA. Yamadazyma riverae sp. nov., a yeast species isolated from plant materials. Int J Syst Evol Microbiol 2015; 65: 4469-4473

[95] Leite J, Fischer D, Rouws LFM, Fernandes-Júnior PI, Hofmann A, Kublik S, Schloter M, Xavier GR, Radl V. Cowpea nodules harbor non-rhizobial bacterial communities that are shaped by soil type rather than plant genotype. Front Plant Sci 2017; 7: 2064

[96] Brum MCP, Araújo WL, Maki CS, Azevedo JL. Endophytic fungi from Vitis labrusca L. ('Niagara Rosada') and its potential for the biological control of Fusarium oxysporum. Genet Mol Res 2012; 11: 4187-4197

[97] Savi DC, Shaaban KA, Vargas N, Ponomareva LV, Possiede YM, Thorson JS, Glienke C, Rohr J. Microbispora sp. LGMB259 endophytic actinomycete isolated from Vochysia divergens (Pantanal, Brazil) producing B-carbolines and indoles with biological activity. Curr Microbiol 2015; 70: 345-354 